\title{
The Serine/Threonine Kinase Ndr2 Controls Integrin Trafficking and Integrin-Dependent Neurite Growth
}

\author{
Kati Rehberg, ${ }^{1}$ Stefanie Kliche, ${ }^{2}$ Deniz A. Madencioglu, ${ }^{1}$ Marlen Thiere, ${ }^{1}$ Bettina Müller, ${ }^{1}$ Bernhard Manuel Meineke, ${ }^{3,4}$ \\ Christian Freund, ${ }^{3,4}$ Eike Budinger, ${ }^{5,6}$ and Oliver Stork ${ }^{1,6}$ \\ ${ }^{1}$ Department of Genetics and Molecular Neurobiology, Institute of Biology, and ${ }^{2}$ Institute for Molecular and Clinical Immunology, Medical Faculty, Otto- \\ von-Guericke University, 39120 Magdeburg, Germany, ${ }^{3}$ Department of Biochemistry, Institute for Chemistry and Biochemistry, Freie Universität Berlin, \\ 14195 Berlin, Germany, ${ }^{4}$ Protein Engineering Group, Leibniz-Institute for Molecular Pharmacology, 13125 Berlin, Germany, ${ }^{5}$ Department of Auditory \\ Learning and Speech, Leibniz-Institute for Neurobiology, 39118 Magdeburg, Germany, and ${ }^{6}$ Center for Behavioral Brain Sciences, 39106 Magdeburg, \\ Germany
}

Integrins have been implicated in various processes of nervous system development, including proliferation, migration, and differentiation of neuronal cells. In this study, we show that the serine/threonine kinase Ndr2 controls integrin-dependent dendritic and axonal growth in mouse hippocampal neurons. We further demonstrate that $\mathrm{Ndr} 2$ is able to induce phosphorylation at the activity- and trafficking-relevant site Thr ${ }^{788 / 789}$ of $\beta 1$-integrin to stimulate the PKC-and CaMKII-dependent activation of $\beta 1$-integrins, as well as their exocytosis. Accordingly, Ndr2 associates with integrin-positive early and recycling endosomes in primary hippocampal neurons and the surface expression of activated $\beta 1$-integrins is reduced on dendrites of Ndr2-deficient neurons. The role of Ndr2 in dendritic differentiation is also evident in vivo, because Ndr2-null mutant mice show arbor-specific alterations of dendritic complexity in the hippocampus. This indicates a role of $\mathrm{Ndr} 2$ in the fine regulation of dendritic growth; in fact, treatment of primary neurons with Semaphorin 3A rescues Ndr2 knock-down-induced dendritic growth deficits but fails to enhance growth beyond control level. Correspondingly, Ndr2-null mutant mice show a Semaphorin $3 \mathrm{~A}^{-1-}$-like phenotype of premature dendritic branching in the hippocampus. The results of this study show that Ndr2mediated integrin trafficking and activation are crucial for neurite growth and guidance signals during neuronal development.

Key words: dendritic and axonal growth; dendritic branching; integrin activation; integrin trafficking; mouse; serine/threonine kinase $\mathrm{Ndr} 2$

\section{Introduction}

Kinases of the Ndr (nuclear Dbf2-related) family are abundantly expressed in neural tissue and play an important role in neuronal differentiation (Emoto, 2011). Current evidence suggests that the Ndr1/2 homologs SAX-1 in Caenorhabditis elegans and tricornered in Drosophila melanogaster are required for neurite initiation and for the control of dendritic branching and tiling (Zallen et al., 1999; Emoto et al., 2004; Gallegos and Bargmann, 2004; Emoto et al., 2006). Consistent with that, expression of dominant-negative Ndr1 and a combined Ndr1/2 knock-down in rat hippocampal neurons enhances, whereas constitutively ac-

\footnotetext{
Received June 26, 2013; revised Feb. 16, 2014; accepted Feb. 24, 2014.

Author contributions: K.R., S.K., and 0.S. designed research; K.R., S.K., D.A.M., M.T., B.M., B.M.M., E.B., and 0.S. performed research; K.R., S.K., C.F., E.B., and 0.S. analyzed data; K.R. and O.S. wrote the paper.

This work was supported by the German Research Foundation (DFG; Grant SFB854 to 0.S., S.K., and C.F. and Grant STO488/3 to 0.S.) and the European Union (ERA-Net on Rare Diseases Project CURE-FXS to 0.S.). K.R. was a scholar of the DFG graduate school (Grant GRK1167). We thank D. Wolters, A. Koffi von Hoff, A. Ramonat, S. Stork, and F. Webers for expert technical assistance; A. Deter and T. Porcuzek for excellent animal care; Y.E. Demiray for experimental support; $D$. Lang for helpful discussions; and M. Kreutz for comments on the manuscript.

The authors declare no competing financial interests.

Correspondence should be addressed to Oliver Stork, Department of Genetic and Molecular Neurobiology, Institute of Biology, Otto-von-Guericke University, Magdeburg, Leipziger Strasse 44, 39120 Magdeburg, Germany. E-mail: oliver.stork@ovgu.de.

DOI:10.1523/JNEUROSCI.2728-13.2014

Copyright $\odot 2014$ the authors $\quad 0270-6474 / 14 / 345342-13 \$ 15.00 / 0$
}

tive Ndr1 reduces, dendritic growth and spine density. Potential Ndr1 substrates involved in control of dendritic growth and spine formation are the endosome-associated Rabin- 8 and AAK (U1tanir et al., 2012), but it is rather likely that further targets downstream of $\mathrm{Ndr} 1 / 2$ will contribute to the complex process of neurite outgrowth and dendrite branching.

Integrins are heterodimeric cell and matrix receptors that provide sites of adhesion and signals for the dynamic rearrangement of cytoskeletal elements in various stages of neuronal differentiation, including outgrowth and branching of axons and dendrites (Moresco et al., 2005; Marrs et al., 2006). Eighteen $\alpha$-subunits and eight $\beta$-subunits have been identified that combine into at least 24 different receptors. $\beta 1$-integrin-containing dimers appear to be particularly relevant for neuronal differentiation because they provide adhesive functions and a versatile signaling platform mediating adhesion contact signaling (Moresco et al., 2005; Marrs et al., 2006).

Integrin binding can be triggered either through an initial low-affinity contact with a suitable substrate ("outside-in") or through the activation of alternative intracellular pathways ("inside-out"), which enhances adhesion by increasing the affinity and avidity of integrin surface receptors (Clegg et al., 2003; Harburger and Calderwood, 2009). This activation involves endosomal trafficking, a coordinated assembly of one $\alpha$-subunit 
and one $\beta$-subunit at the membrane, the exposure of their extracellular binding domains, and the intracellular association of signaling factors and linkers to the actin cytoskeleton, such as filamins, talins, and kindlins (Larjava et al., 2008; Abram and Lowell, 2009; Huveneers and Danen, 2009; Moser et al., 2009a). In developing and mature neurons, both the adhesive function and the integrin-mediated signaling to the actin cytoskeleton are well documented (Clegg et al., 2003; Bernard-Trifilo et al., 2005). Intriguingly, Ndr2 and tricornered associate with the actin cytoskeleton, suggesting a role in cytoskeletal reorganization during cell polarization and neurite formation (Stork et al., 2004; Fang and Adler, 2010). However, whereas integrin activation mechanisms have been investigated in detail in non-neuronal cells (Gahmberg et al., 2009; Margadant et al., 2011), they are still not sufficiently understood in neurons.

In this study, we provide evidence that $\mathrm{Ndr} 2$ contributes to dendrite outgrowth and branching by stimulating the phosphorylation and endosomal trafficking of $\beta 1$-integrins, thereby controlling integrin-dependent differentiation of hippocampal neurons both in vitro and in vivo.

\section{Materials and Methods}

DNA constructs and antibodies. Cloning of Ndr2 and generation of EGFP$\mathrm{Ndr} 2$ fusion proteins has been described previously (Stork et al., 2004) and $\mathrm{mCherry}$ fusion constructs were generated in the same way using SalI and BglI restriction endonuclease digestion (New England Biolabs). Plasmids pCMV-tdTomato and pEGFP-C1 were purchased from Clontech. To generate a constitutive active Ndr2 (Stork et al., 2004) and Mst1 (purchased from the Harvard Plasmid Bank), full-length cDNA clones were amplified by PCR and cloned either into the pEFBOS-LAT vector or the pEFBOS-Flag vector as described previously (Boerth et al., 2000). Specific shRNA against murine Ndr2 (5'-CCT-CAT-CTG-CCA-ATCCCT-C-3'), murine $\beta 1$-integrin (according to \#2 shITGB1 from Lei et al. (2012) and commercial anti-luciferase shRNA from pMIR-mU6-Luc (Mirus Bio), was used as a control and cloned into pLL.3.7 vector (Addgene). RNAi rescue experiment where achieved by cloning the sequence of Ndr2 shRNA together with an shRNA-resistant EGFP-Ndr2 gene (with five point mutations, the sequence was changed from $5^{\prime}$-GAAGGA-TTG-GCA-GAT-GAG-3' to 5'-GAG-GGT-TTG-GCC-GACGAA-3' ${ }^{\prime}$, causing no change of encoded amino acids but mismatching of Ndr2 shRNA) into the pLL3.7 vector backbone. Generation and purification of a GST fusion protein of the cytoplasmic domain of $\beta 1$-integrin was done as described previously (Moser et al., 2009b). The GSTFilamin-A 19-24 pGEX clone was generously provided by Dr. Martin Humphries (Manchester University). The construct pECFP-SARAFYVE was a gift from S. Corvera (Hayakawa et al., 2004).

The primary antibodies anti-caveolin1 (Santa Cruz Biotechnology), anti-Mst1 and anti-pT183 Mst1 (Cell Signaling Technologies), antiNdr1 (MyBioSource), anti-actin (Millipore), anti- $\beta$-actin (Abcam), and anti $\beta$-galactosidase (Promega) were used for immunoblotting. AntiGFP (Abcam), anti-pT ${ }^{788 / 789} \beta 1$-integrin (Abcam), anti-Rab11 (BD Bioscience PharMingen), and anti-Rab5 (Synaptic Systems) primary antibodies were used for immunoblotting and immunocytochemistry. For detecting Ndr2 kinase, we used our c-terminal-binding antibody abNdr2 described by Stork et al. (2004). For flow cytometric analysis, FITClabeled or nonconjugated anti-CD29 ( $\beta 1$-integrin, clone MEM101A) were purchased from Immunotools; FITC-conjugated anti-mouse IgG were from Dianova. Primary antibodies anti-MAP2 (Abcam), anti- $\beta 1$ integrin (BioLegend) and 9EG7 antibody against activated $\beta 1$-integrin were used for immunocytochemistry. Alexa Fluor dye and Cy-coupled secondary antibodies (Invitrogen and Dianova) were used for immunofluorescence analysis. HRP-coupled secondary antibodies for ECL Western blot detection were purchased from Dianova and GE Healthcare.

NIH 3 T3 and HEK-293T culture. Cell lines were maintained in DMEM containing $10 \%$ fetal bovine serum and penicillin/streptomycin (100 $\mathrm{U} / \mathrm{ml} / 100 \mu \mathrm{g} / \mathrm{ml}$; all from Invitrogen). HEK-293T cells were transiently transfected using the standard calcium phosphate precipitation method.
When indicated, the transfected cells were treated with $1 \mu \mathrm{M}$ okadaic acid (Merck) for $1 \mathrm{~h}$ before harvesting. To analyze potential dependency of $\beta 1$-integrin phosphorylation at $\mathrm{Thr}^{788 / 789}$ on the calcium-calmodulindependent kinase II (CaMKII) and the protein kinase $\mathrm{C} \varepsilon(\mathrm{PKC} \varepsilon)$ kinase activity, cells were treated with autocamtide- 2 related inhibitory peptide II $(0.1 \mu \mathrm{M}$, cell-permeable; Tocris Bioscience) or Ro-31-7549 (0.35 $\mu \mathrm{M}$; Merck) according to the manufacturers' specifications.

Isolation of lipid rafts and non-lipid-raft fractions. Preparation of lipid rafts by sucrose gradient centrifugation has been described previously (Boerth et al., 2000). HEK 293T cells $\left(2 \times 10^{6}\right.$ cells) were lysed in morpholine-propane-sulponic acid (MES)-buffered saline (25 mM MES, pH 6.5, $150 \mathrm{~mm} \mathrm{NaCl}$ ) containing $1 \%$ Triton X-100 and 1 mm PMSF. The lysates were mixed with $1 \mathrm{ml}$ of $80 \%$ sucrose and overlaid with $2 \mathrm{ml}$ of $30 \%$ sucrose and $1 \mathrm{ml}$ of $5 \%$ sucrose all solved in MES-buffered saline. After centrifugation $\left(200,000 \times g\right.$ for $18 \mathrm{~h}$ at $\left.4^{\circ} \mathrm{C}\right)$, fractions were removed sequentially starting from the top of the gradient. Anti-caveolin 1 antibody was used to identify lipid rafts fractions on a dot blot assay. Rafts fraction $(2-4)$ and non-raft fractions $(8-10)$ were pooled and analyzed by Western blotting.

Isolation of endosome fractions. Endosome fractionation experiments were done with neural differentiated rat pheochromocytoma (PC-12) cells using a sucrose gradient centrifugation adopted from Waugh et al. (2011). Cells were grown in RPMI-1640 with 2 mM L-glutamine, 10\% horse serum, $5 \%$ fetal bovine serum (all reagents from Invitrogen). Then, $30 \times 10^{6}$ PC- 12 cells were harvested and lysed using a manual homogenizer in a buffer containing $250 \mathrm{~mm}$ sucrose, $100 \mathrm{~mm}$ triethanolamine, $100 \mathrm{~mm}$ acetic acid, $1 \mathrm{~mm}$ EDTA, $1 \mathrm{~mm}$ PMSF, and complete proteinase inhibitor (Roche). Lysate was overlaid on a continuous $10-40 \%$ sucrose gradient. After $20 \mathrm{~h}$ of centrifugation (at 75,000 $\times \mathrm{g}$ ), 10 fractions were aliquoted from the top and analyzed by Western blotting and immunodetection of intracellular membrane organelles. Specificity of fraction was tested with markers for endosomes, mitochondria, endoplasmic reticulum, and the Golgi apparatus (data not shown).

Western blot analysis, immunoprecipitation, and in vitro kinase assay. For phosphoprotein isolation, cells were washed once with ice-cold PBS, lysed in lysis buffer containing $1 \%$ lauryl maltoside $N$-dodycyl$\beta$-D-maltoside (Merck), $1 \% \mathrm{NP}-40$ (Sigma-Aldrich), $1 \mathrm{~mm} \mathrm{Na-}$ orthovanadate, $1 \mathrm{~mm}$ PMSF, $50 \mathrm{~mm}$ Tris-HCl, pH 7.4, $10 \mathrm{~mm} \mathrm{NaF,} 10 \mathrm{~mm}$ EDTA, and $160 \mathrm{~mm} \mathrm{NaCl}$ and incubated for $20 \mathrm{~min}$ on ice. After centrifugation, the protein concentration of the postnuclear supernatant was determined using the Roti-Nanoquant reagent (Roth) according to the manufacturer's instructions. Equivalent amounts of protein were used in precipitation studies ( $500 \mu \mathrm{g}$ of total protein). Ndr2 was immunoprecipitated using anti-Ndr2 antibody in combination with $30 \mu \mathrm{l}$ of protein-A agarose beads (Santa Cruz Biotechnology) for $2 \mathrm{~h}$ at $4^{\circ} \mathrm{C}$. Precipitates were washed 3 times in NP-40 washing buffer $(0.1 \%$ NP- 40,1 mм PMSF, $50 \mathrm{~mm}$ Tris-HCl pH 7.4, $10 \mathrm{~mm} \mathrm{NaF}$, and $160 \mathrm{~mm} \mathrm{NaCl}$ ). Cell lysates ( $50 \mu \mathrm{g}$ of total protein) or immune complexes were separated by SDS-PAGE and transferred to nitrocellulose and PVDF (Millipore) membrane, respectively. Western blots were conducted with the indicated primary antibodies and the appropriated HRP-conjugated secondary antibodies and analyzed with a Luminol detection system from Roth and Millipore, respectively. For in vitro kinase assays, precipitates were washed three times in NP-40 washing buffer; for some experiments, samples were divided into two equal aliquots. Both samples were pelleted and one used for Western blot analysis; the other was washed 3 times and resuspended in kinase buffer ( $25 \mathrm{mM}$ HEPES, $10 \mathrm{mM} \mathrm{MgCl}_{2}, 1 \mathrm{~mm}$ dithiothreitol, and $100 \mu \mathrm{M}\left[\gamma_{-}{ }^{32} \mathrm{P}\right] \mathrm{ATP}, \sim 1 \mu \mathrm{Ci} / \mu \mathrm{l}$; PerkinElmer) supplemented with $5 \mu \mathrm{g}$ of myelin basic protein (Merck), GST, and GST-cyt $\beta 1$ and incubated for $30 \mathrm{~min}$ at $30^{\circ} \mathrm{C}$. Reactions were stopped by addition of $5 \times$ sample buffer and proteins were resolved by SDS-PAGE. After drying, the gels were exposed to autoradiography films. The generation and purification of the GST fusion protein for the cytoplasmic domain of $\beta 1$-integrin has been described previously (Moser et al., 2009b).

Analysis of $\beta 1$-integrin recycling. Twenty-four hours after transfection, HEK-293T cells were resuspended in PBS and $0.5 \times 10^{6}$ cells were stained for $30 \mathrm{~min}$ at $4^{\circ} \mathrm{C}$ with FITC-labeled CD29 antibodies (or antimouse IgG conjugated with FITC as a negative control). After labeling, cells were incubated for various time points at $37^{\circ} \mathrm{C}$ and the remaining 


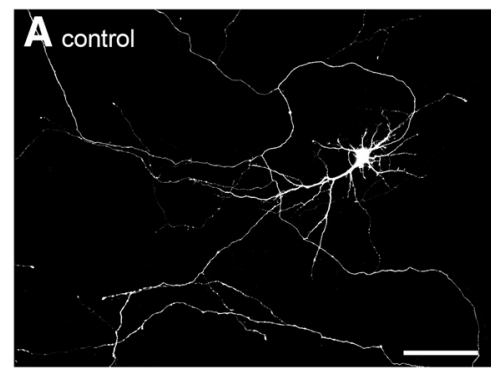

D

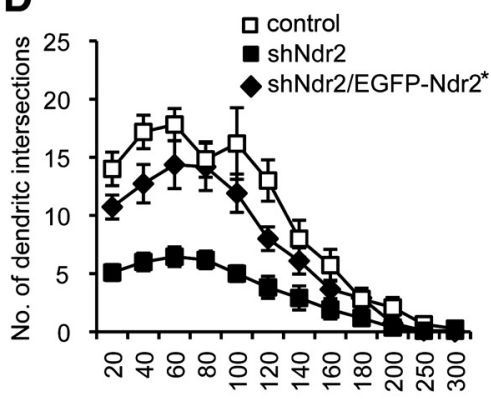

$\mu \mathrm{m}$ to the center of the soma

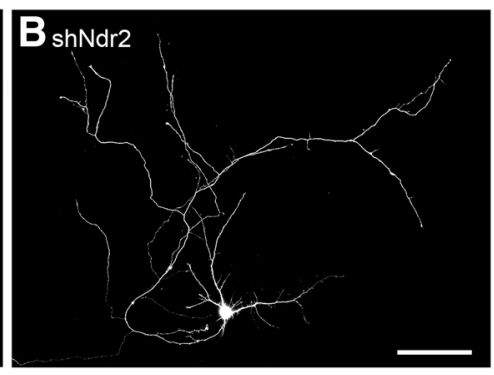

E

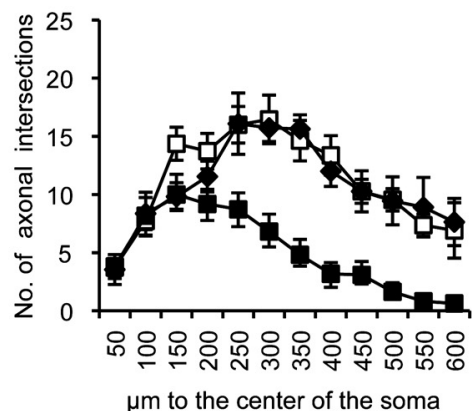

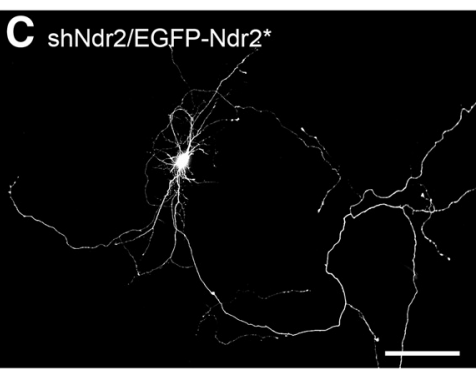

$\mathbf{F}$

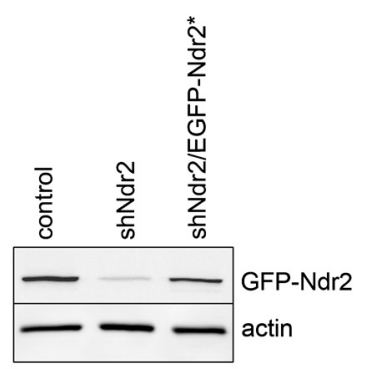

G

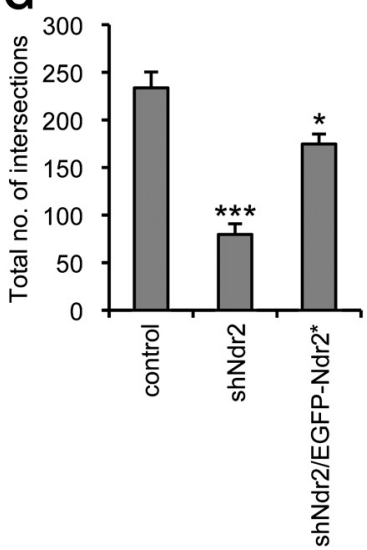

H

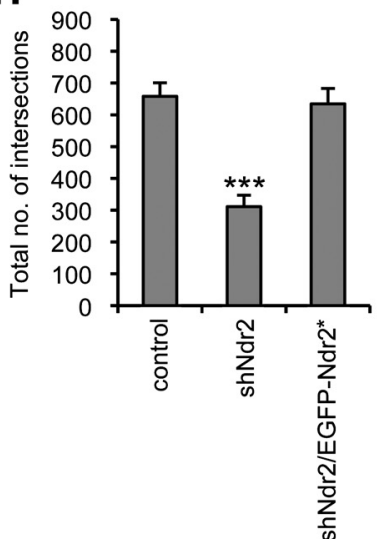

I

PO

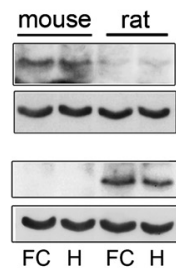

P10

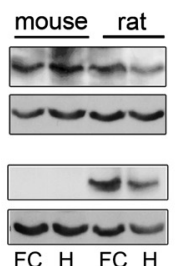

P20

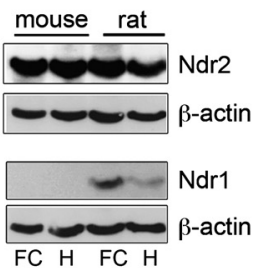

Figure 1. Ndr2 is required for neurite growth in mouse hippocampal neurons. Cells were transfected with tdTomato and shLuc as control shRNA (control; $\boldsymbol{A}$ ), with tdTomato and shRNA directed against Ndr2 (shNdr2; $\boldsymbol{B}$ ), or with tdTomato, shRNA directed against Ndr2 (shNdr2; $\boldsymbol{C}$ ) together with an shNdr2-insensitive form of EGFP-Ndr2. Neurons (DIV 7) with Ndr2 knock-down show a drastic reduction of both the dendritic tree and the axon. This reduction was detained by a coexpression of EGFP-labeled Ndr2. Scale bars, $100 \mu \mathrm{m}$. Quantitative analysis of dendrites $(\boldsymbol{D}, \boldsymbol{G})$ and axons $(\boldsymbol{E}, \boldsymbol{H})$ using the Sholl analysis ( $n=12$ cells each; $N=3$ ) confirms their profoundly reduced density upon Ndr2 knock-down and the recovery by the shNdr2-insensitive EGFP-Ndr2. Data are presented as mean \pm SEM. ${ }^{*} p<0.05 ;{ }^{* * *} p<0.001$ (Fischer's PLSD). $\boldsymbol{F}$, Efficiency of the shNdr2 is revealed by the suppression of cotransfected GFP-Ndr2 in HEK-293T. Further transfection with the shNdr2/EGFP-Ndr2* reconstitution construct prove the shNdr2 insensitivity of EGFP-Ndr2*. Double transfection with the control shRNA shLuc (control) does not alter GFP-Ndr2 levels. I, Ndr2, but not $\mathrm{Ndr1}$, is prominently expressed in mouse frontal cortex (FC) and hippocampus (Hip) during development. In contrast, both kinases are found in rat tissue at P0, P10, and P20.

and $5 \mathrm{~mm} \mathrm{~K}_{3} \mathrm{Fe}(\mathrm{CN})_{6}$. After washing with tap water, sections were embedded with Immumount.

Golgi impregnation was done as described previously (Mylius et al., 2013). Brains were removed and impregnated in the dark for $14 \mathrm{~d}$ at room temperature in a Golgi-Cox solution (Glaser and Van der Loos, 1981), dehydrated, and embedded with celloidin. After polymerization, $150-\mu \mathrm{m}$-thick horizontal sections were cut on a sliding microtome (Microm), collected in $70 \%$ ethanol, and rinsed in aqua dest before being treated with $50 \%$ alkaline ammonia followed by $0.5 \%$ phenylenediamine (Sigma-Aldrich). Staining was developed in 1\% Dectol (Kodak) and fixated in 5\% Tetenal (Calbe Fotochemie). Finally, sections were rapidly dehydrated in a graded series of ethanol and xylol (Roth) and mounted between two coverslips using Merckoglas (Merck). The brain morphology of wild-type and Ndr2 ${ }^{-1-}$ mice was inspected and analyzed using a light microscope system (DMRX; Leica) with a motorized stage (Märzhäuser). Representative pyramidal neurons of the left and right $\mathrm{CA} 3$ at the level of the root region of the fimbria were analyzed for initial dendrite segment length. Some of them were further reconstructed by means of the Neurolucida software (Microbrightfield). For the quantitative analysis of their branching patterns, we used Neuroexplorer software (Microbrightfield) and the Excel spreadsheet application.

Statistical analysis. Statistical analysis on multiple groups was performed with multivariate ANOVA followed by Fischer's protected least significant difference (PLSD) test. For direct pairwise comparisons, Student's $t$ test or the nonparametric Mann-Whitney $U$ test was applied. A statistical value of $p<0.05$ was considered significant.

\section{Results}

$\mathrm{Ndr} 2$ is involved in dendrite and axon development in mouse hippocampal neurons

In primary hippocampal neurons, $\mathrm{Ndr} 2$ is localized in the soma, dendrites, axons, and presynaptic and postsynaptic sites 

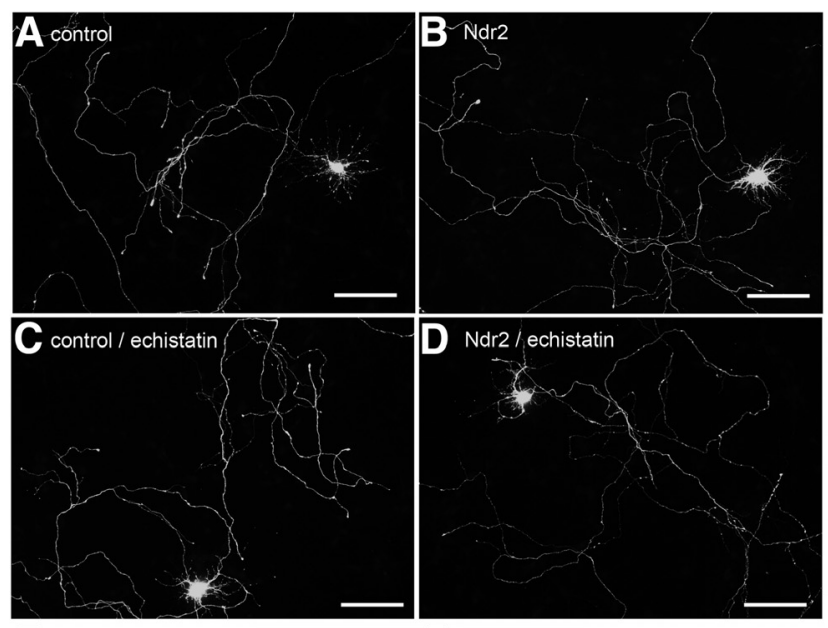

\section{E}

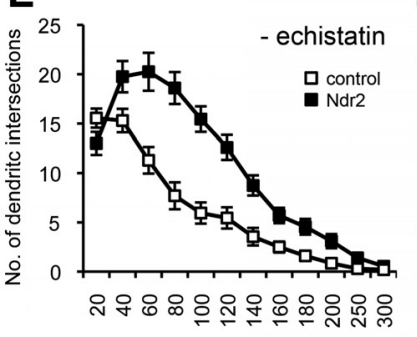

G $\mu \mathrm{m}$ to the center of the soma

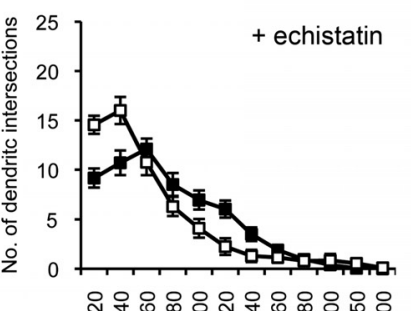

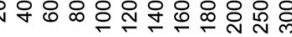

$\mu \mathrm{m}$ to the center of the soma
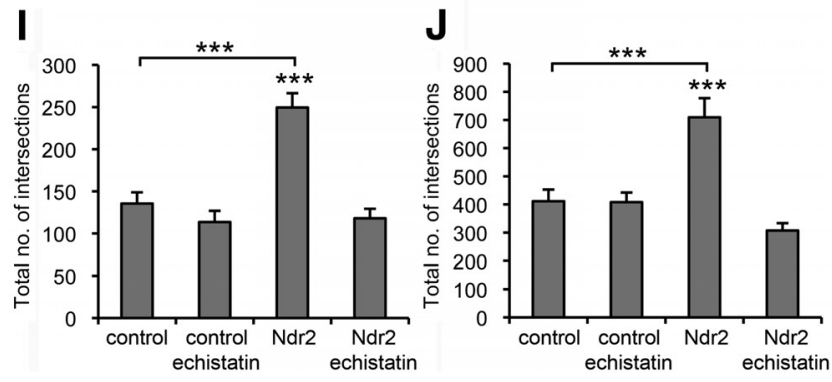

$\mathbf{F}$

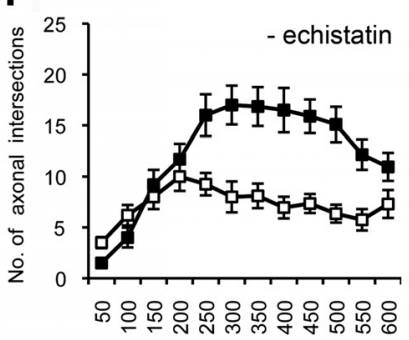

H

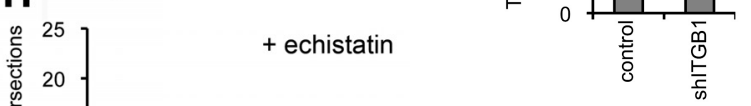

E

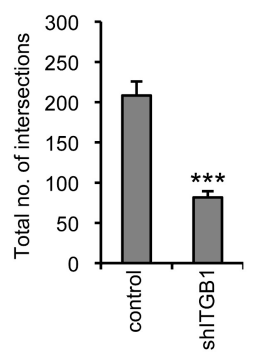

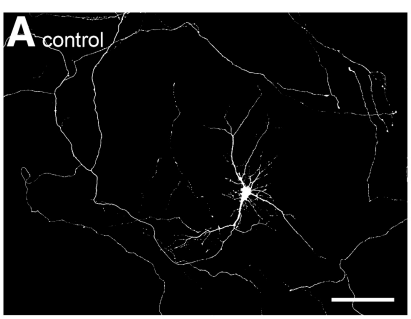

C

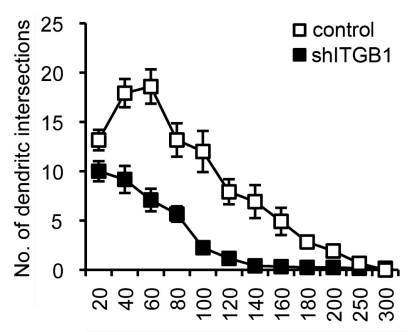

$\mu \mathrm{m}$ to the center of the soma

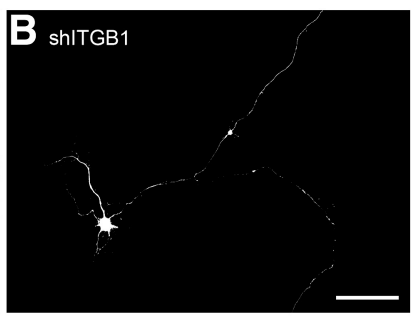

D

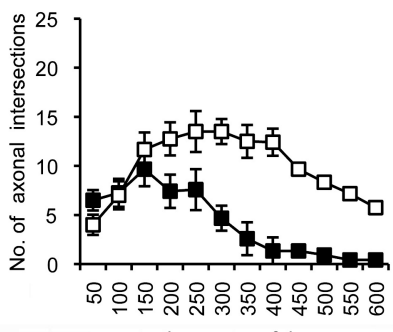

$\mu \mathrm{m}$ to the center of the soma

G

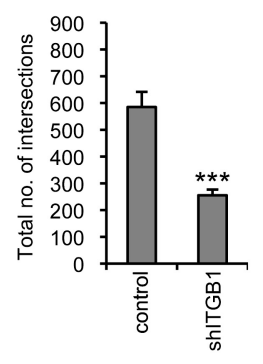

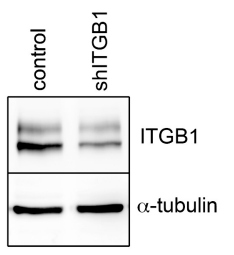

Figure 3. Reduced $\beta 1$-integrin expression leads to a reduced dendritic and axonal growth in mouse hippocampal neurons. Cells were transfected with tdTomato and shLuc as control shRNA (control; $\boldsymbol{A})$, or with tdTomato and shRNA directed against $\beta 1$-integrin (shlTGB1; $\boldsymbol{B}$ ). Knockdown of $\beta 1$-integrin at DIV 7 exhibits a drastically reduced growth and branching of either dendrites $(\boldsymbol{C}, \boldsymbol{E})$ or axons $(\boldsymbol{D}, \boldsymbol{F})$ using the Sholl analysis ( $n=12$ cells each; $N=3$ ). Data are presented as mean \pm SEM. ${ }^{* * *} p<0.001$ (Fischer's PLSD). Scale bars, $100 \mu \mathrm{m}$. (G) Efficiency of shITGB1 was proven in the murine cell line NIH3T3.

Figure 2. Ndr2-mediated dendritic and axonal growth effects are integrin dependent. $\boldsymbol{A}-\boldsymbol{D}$, Primary hippocampal neurons were transfected with EGFP (control; $A, C$ ) or with both EGFP and

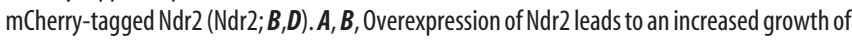
both dendrites and axons compared with control cells (DIV 7). C, D, Under treatment with echistatin, no difference can be observed between Ndr2-transfected primary neurons and controls. Scale bars, $100 \mu \mathrm{m} . E, F$, Quantitative analysis $(n=20$ cells each; $N=3$ ) of dendritic and axonal arbors confirms the significant increase upon Ndr2 overexpression. $\boldsymbol{G}, \boldsymbol{H}$, Under echistatin treatment, no enhancement of growth and branching is evident in the Ndr2-overexpressing cells. In fact, axons show a slight reduction of arborization. I, J, Cross-comparison of the total number of intersections with untreated neurons demonstrates that echistatin normalizes the number of dendritic and axonal branches in Ndr2-overexpressing cells to control level, whereas EGFP-transfected control cells are not affected by the disintegrin. Data are presented as mean \pm SEM. ${ }^{* * *} p<0.001$ (Fischer's PLSD).

(Stork et al., 2004). When analyzing the expression of Ndr2 mRNA in hippocampal cultures, we found that levels correlated with the formation and maturation of dendrites (ANOVA $F_{(6,25)}=3.9, p=0.011$ ), increasing 1.54-fold ( \pm 0.24$)$ from DIV 3 to a maximum at DIV 7 and decreasing on DIV $14(0.89 \pm 0.20)$ and on DIV $21(0.70 \pm 0.12)$. Ndr1 mRNA was $>100$-fold lower than Ndr2 at all time points and was hardly detectable. In fact, Western analysis revealed that Ndr2, but not $\mathrm{Ndr} 1$, is expressed in the mouse hippocampus and frontal cortex during development (Fig. 1I). In contrast, in rats, both Ndr kinases could be observed, as described previously (Ultanir et al., 2012). The increase in Ndr2 mRNA expression during the period of extensive dendritic and axonal growth between DIV 3 and DIV 7 (Goslin and Banker, 1990) prompted us to investigate the relevance of the kinase in neurite outgrowth of mouse hippocampal neurons.

First, we found that shRNA-mediated knock-down of Ndr2 led to a significant reduction in the growth of both dendrites (repeatedmeasures ANOVA with the between-subject factor gene and the within-subject factor distance: $\left.F_{(1,38)}=49.816, p<0.001\right)$ and axons $\left(F_{(1,38)}=23.184, p<0.001\right)$ as determined by Sholl analysis $(n=20$ cells each; $N=3$, data not shown). In a second set of experiments (Fig. $1 A-H$ ), we also used a reconstitution vector coexpressing shRNA-resistant Ndr2, with which we confirmed the Ndr2 knockdown-induced reduction and, moreover, demonstrated its recovery in both dendrites (repeated-measures ANOVA with the betweensubject factor gene and the within-subject factor distance: $F_{(2,33)}=$ 
A
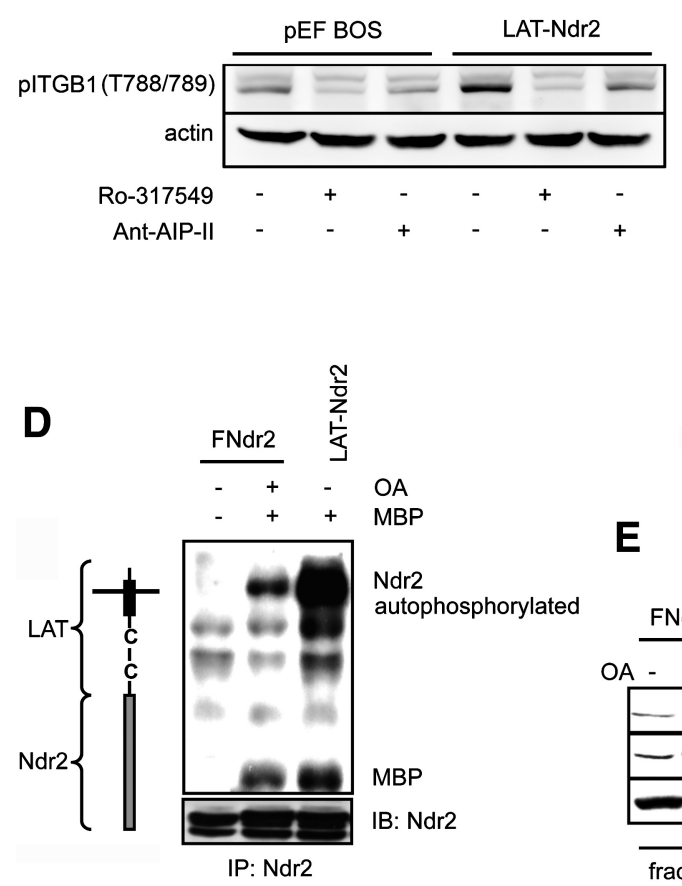

E
B

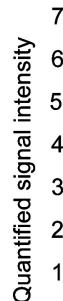

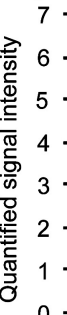

pITGB1 (T788/789)

C

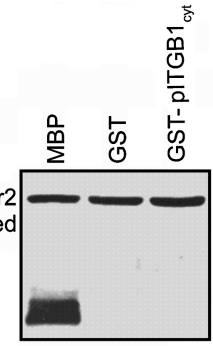

IP: LAT-Ndr2

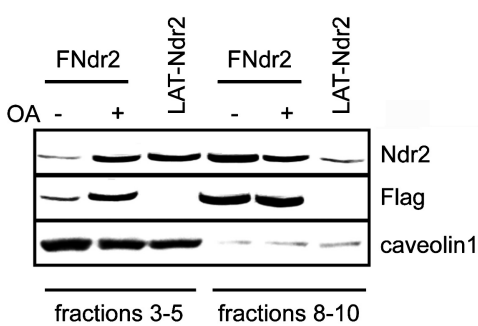

F

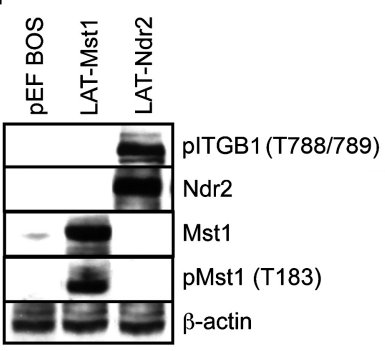

Figure 4. Ndr2 stimulates phosphorylation of $\beta 1$-integrin. $\boldsymbol{A}, \beta 1$-integrin phosphorylation at Thr ${ }^{788 / 789}$ is increased in HEK-293T cells upon overexpression of LAT-Ndr2. The increase is prevented through application of the CaMKII inhibitor Ant-AIP-II or the PKC inhibitor Ro-317549. B, Quantification of Western blot signals confirms a significant increase of $\beta 1$-integrin Thr ${ }^{788 / 789}$ phosphorylation upon LAT-Ndr2 expression and its blockage by Ant-AIP-II and Ro-317549, respectively $(N=3)$. Data are presented as mean \pm SEM. ${ }^{* *} p<0.01$ compared with control transfection (pEFBOS). C, In an in vitro kinase assay, however, constitutively active LAT-Ndr2 fails to phosphorylate the intracellular domain of $\beta 1$-integrin. Autophosphorylation of LAT-Ndr2 and transphosphorylation of MBP confirm the activity of the kinase. D, Scheme of membrane-anchored, constitutively active LAT-Ndr2 and activity of precipitated Flag-Ndr2 (FNdr2) or LAT-Ndr2 in an in vitro kinase assay. Autophosphorylation of FNdr2 can be induced with ocadaic acid (OA) treatment of transfected cells, whereas LAT-Ndr2 is constitutively autophosphorylated. Myelin basic protein (MBP) serves as a positive control. $E$, Western blot analysis of lipid rafts (3-5) and nonrafts (8-10) membrane fractions reveals a localization of both ocadaic-acid-stimulated FNdr2 and LAT-Ndr2 in lipid rafts of transfected HEK-293T cells. Caveolin1 serves as a marker for the lipid rafts fractions. $\boldsymbol{F}$, LAT-Mst1 overexpression in HEK293 cells results in increased phosphorylation of Mst1 at Thr ${ }^{183}$ compared with control conditions (pEFBOS transfected). However, constitutively active LAT-Mst1, in contrast to LAT-Ndr2, fails to increase $\beta 1$-integrin phosphorylation at Thr ${ }^{788 / 789}$ of $\beta 1$-integrin.

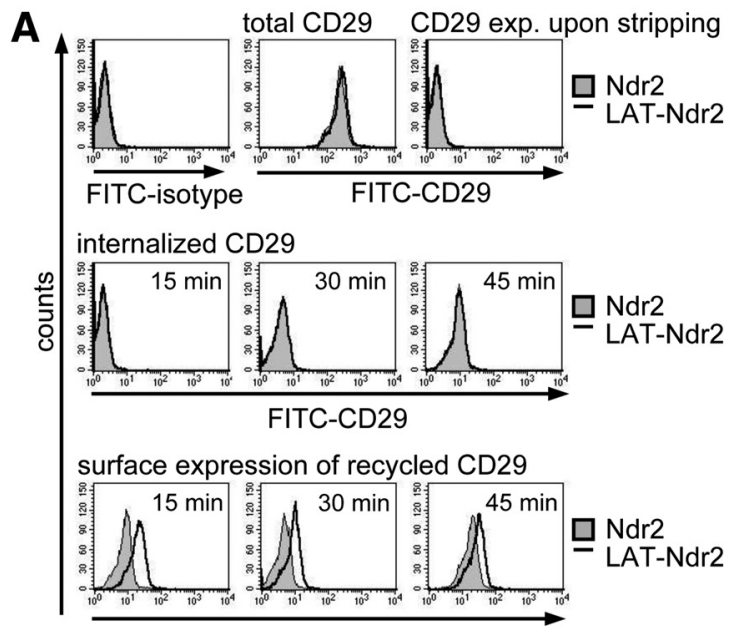

FITC-CD29

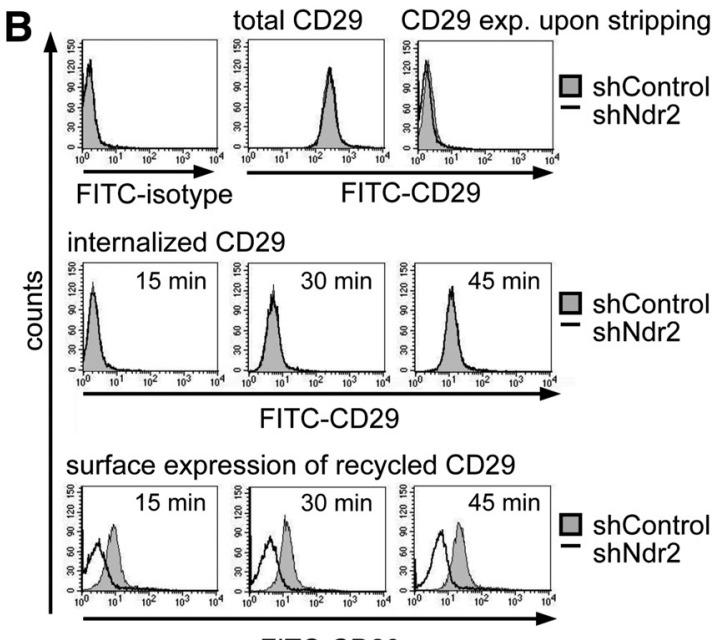

FITC-CD29

Figure 5. Ndr2 stimulates $\beta 1$-integrin exocytosis. Flow cytometric analysis of $\beta 1$-integrin (CD29) surface expression was performed in HEK-293T cells. $\boldsymbol{A}, \boldsymbol{B}$, Expression of constitutively active LAT-Ndr2 ( $\boldsymbol{A}$ ) and Ndr2 knock-down with shNdr2 (B) do not affect total $\beta 1$-integrin expression or surface expression in unstimulated cells (top). Moreover, no effect is observed on the stimulated endocytosis of $\beta 1$-integrin ("internalized CD29," middle). However, LAT-Ndr2 increases and shNdr2 reduces recycling of $\beta 1$-integrin 15 to 45 min after induction of exocytosis "surface expression of recycled (D29," bottom). $\boldsymbol{A}$ and $\boldsymbol{B}$ each show one representative experiment of three.

33.075, $p<0.001$, and axons: $\left.F_{(2,33)}=20.745, p<0.001\right)$. Comparing the total number of intersections, Ndr2 shRNA expression led to a significant reduction in the growth of both dendrites (Fischer's PLSD, $p<0.001)$ and axons $(p<0.001)$ compared with control- transfected neurons. The reconstitution of Ndr2 expression resulted in an increase of dendritic $(p<0.001)$ and axonal branching $(p<$ $0.001)$ compared with shNdr2-transfected neurons, reaching levels comparable to those of controls. 
Ndr2-sensitive neurite development is integrin dependent

Overexpression of Ndr2 leads to significant increase in dendritic growth (repeated-measures ANOVA with the between-subject factor gene and the within-subject factor distance: $F_{(1,39)}=$ 28.013, $p<0.001)$ without any change in the number of primary dendrites evading the soma. Moreover, axonal growth of Ndr2 overexpression neurons was strongly enhanced $\left(F_{(1,39)}=13.991, p=\right.$ $0.001)$, thus supporting the growthstimulating function of $\mathrm{Ndr} 2$ in our experiments (Fig. $2 A, B, E, F$ ). In primary cell culture, astrocytic deposition of extracellular matrix components strongly activates integrin-dependent neuronal growth (Nishio et al., 2003) and the RGDreceptors $\alpha 5 \beta 1$-integrin and $\alpha \mathrm{v} \beta 3$ integrin appear to be critical for dendrite development (Gupton and Gertler, 2010; McGeachie et al., 2011). With application of the RGD disintegrin echistatin, we were indeed able to entirely prevent the Ndr2-enhanced dendritic growth (repeated-measures ANOVA: $F_{(1,39)}=$ 0.064, $p=0.802$ compared with echistatin-treated control cells) and furthermore to slightly reduce axonal growth $\left(F_{(1,39)}=5.419, p=0.025\right)$ in $\mathrm{Ndr} 2-$ overexpressing cells (Fig. 2C,D,G,H). Comparison with untreated Ndr2overexpressing cells confirmed the blockage of Ndr2-induced overgrowth of both types of neurites through echistatin (Fischer's PLSD, $p<0.001$; Fig. $2 I, J$ ).

Because echistatin blocks both $\beta 1$ - and $\beta 3$-integrin-containing dimers, we tested the mRNA levels of these two $\beta$ isoforms at early developmental stages of hippocampal neurons. We found that mRNA levels of $\beta 3$-integrin were $<0.5 \%$ of $\beta 1$ integrin mRNA expression levels at DIV 3, DIV 5, and DIV 7. Therefore, we focused on testing the function of $\beta 1$-integrin in neurite growth and arborization by expressing a shRNA that partially knocked down the endogenous $\beta 1$-integrin protein (Fig. 3G). We found both dendritic (repeated-measures ANOVA with the between-subject factor gene and the withinsubject factor distance: $\left.F_{(1,22)}=45.013, p<0.001\right)$ and axonal $\left(F_{(1,22)}=32.363, p<0.001\right)$ branches to be drastically reduced (Fig. $3 A-F$ ), akin to the shNdr2 phenotype.

\section{Ndr2 controls $\boldsymbol{\beta} 1$-integrin phosphorylation at $\mathrm{Thr}^{788 / 789}$}

We next tested whether Ndr2 may phosphorylate the cytoplasmic domain of the $\beta 1$-integrin subunit. Expression of a membrane targeted, constitutively active form of Ndr2 (LAT-Ndr2) in fact did increase $\beta 1$-integrin phosphorylation (3.91 \pm 0.94 -fold, $p=$ 0.001 , Student's $t$ test) at $\mathrm{Thr}^{788 / 789}$ in HEK-293T cells (Fig. $4 A, B)$. CaMKII and PKC $\varepsilon$ have been reported previously to mediate $\beta 1$-integrin phosphorylation at this site (Suzuki and Takafractions.
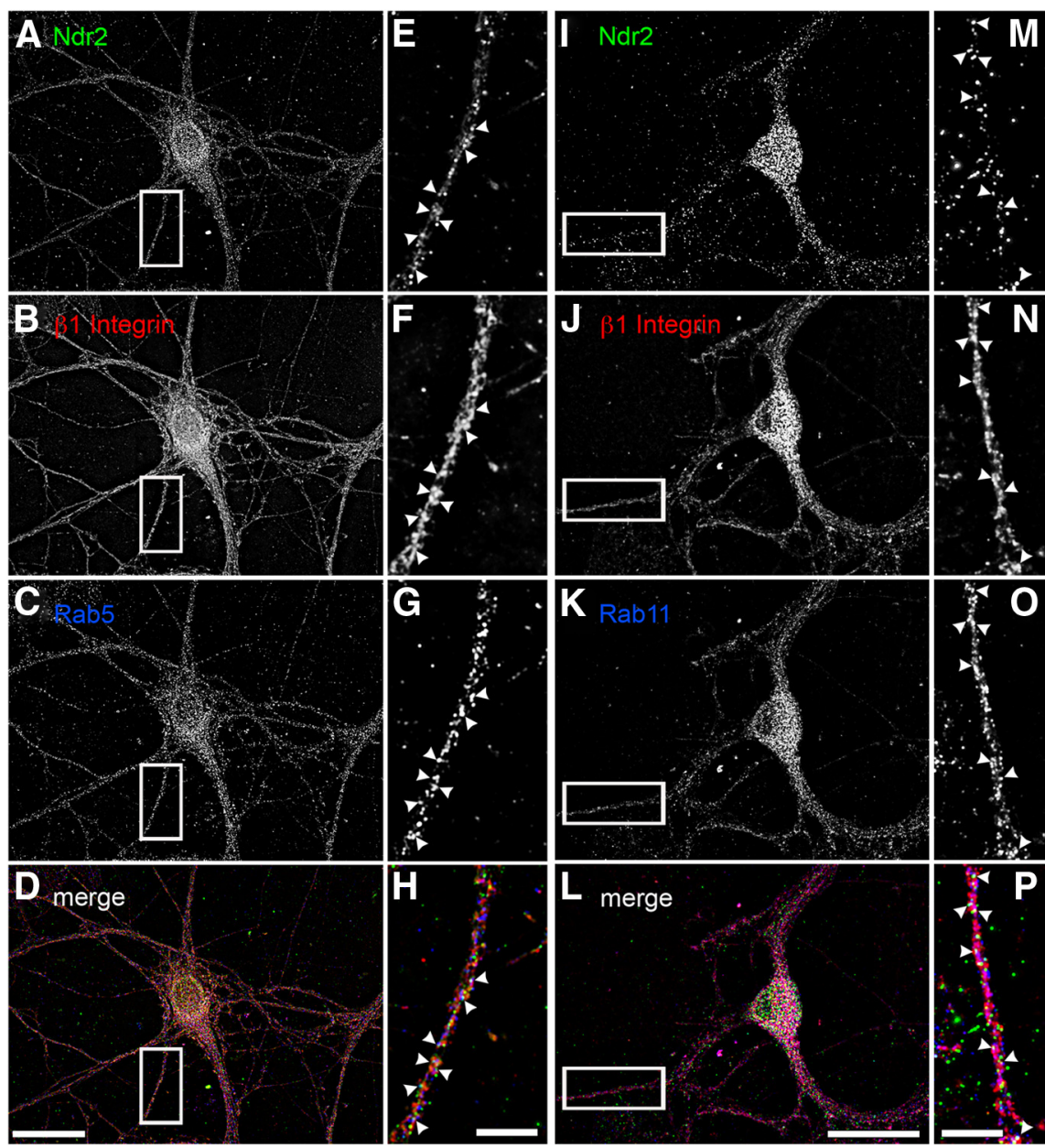

Figure 6. $\mathrm{Ndr2}$ associates with $\beta 1$-integrin-positive early and recycling endosomes. Colocalization of endogenous $\mathrm{Ndr} 2$ (green) and $\beta 1$-integrin (red) can be observed with the early endosome marker Rab5 $(\boldsymbol{A}-\boldsymbol{H})$ and with Rab11 (I-P) (both lue), a marker for recycling endosomes in somata, dendrites, and axons. Arrowheads depict sites of costaining in proximal neural differentiated PC12 cells indicates that Ndr2 is selectively detected only in Rab5- and Rab11-positive endosome

hashi, 2003; Stawowy et al., 2005). In fact, LAT-Ndr2 induced phosphorylation at $\mathrm{Thr}^{788 / 789}$ was sensitive to Ant-AIP-II and Ro-317549, which are specific inhibitors of CaMKII (Ishida et al., 1995) and PKC activity (Turner et al., 1994), respectively. Ndr2 did not directly phosphorylate $\beta 1$-integrin because we were not able to detect phosphorylated cytoplasmic domain of $\beta 1$-integrin in an in vitro kinase assay using either LAT-Ndr2 (Fig. 4C) or ocadaic-acid-stimulated native Ndr2 (data not shown). At the same time, autophosphorylation of $\mathrm{Ndr} 2$ and phosphorylation of the myelin-binding protein were clearly evident (Fig. 4D) and an association of activated Ndr2 with the lipid rafts fraction of the plasma membrane was verified (Fig. 4E). Finally, expression of constitutively active Mst1 kinase did not stimulate $\mathrm{Thr}^{788 / 789}$ phosphorylation of $\beta 1$-integrin in HEK-293T cells (Fig. 4F). 


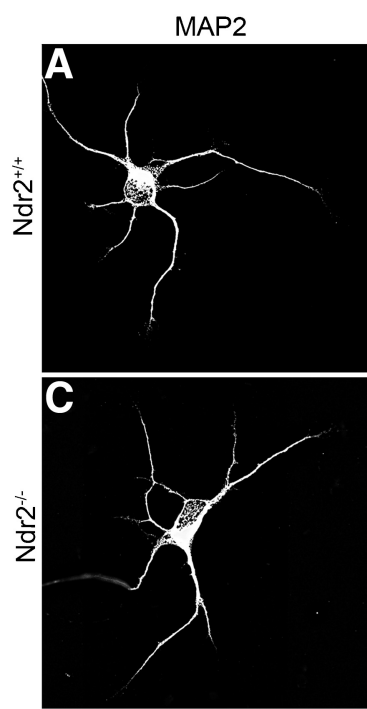

E

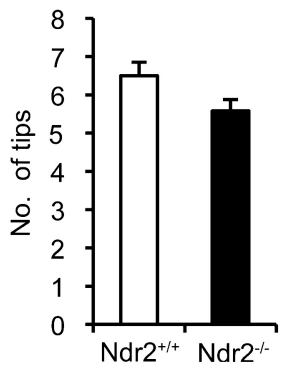

$\beta 1$-integrin (9EG7)
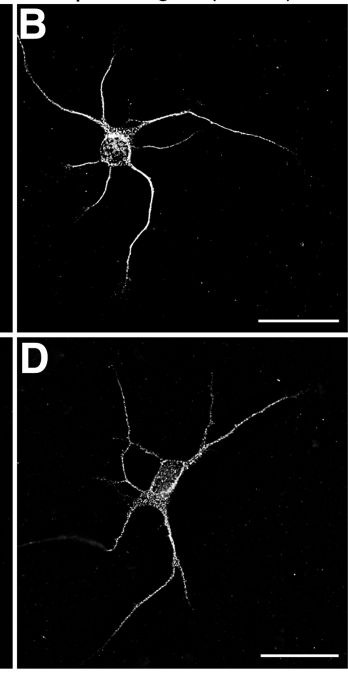

$\mathbf{F}$

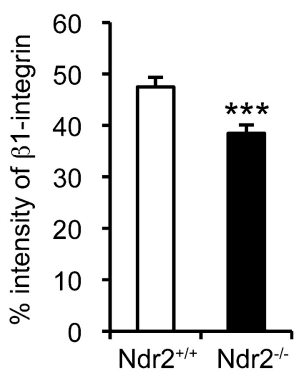

G
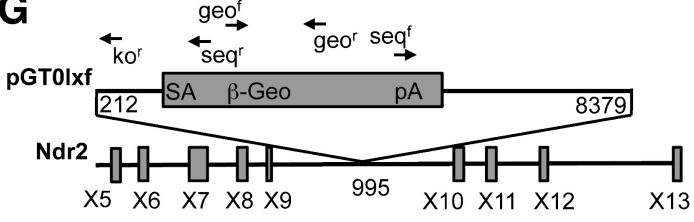

wt/ ko $\stackrel{\leftarrow}{\rightarrow} \leftarrow t^{r}$

H

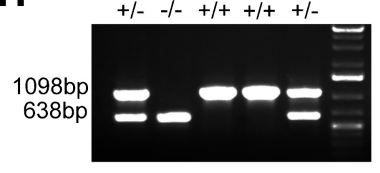

I

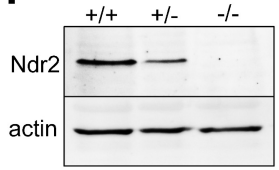

J $\quad$ K
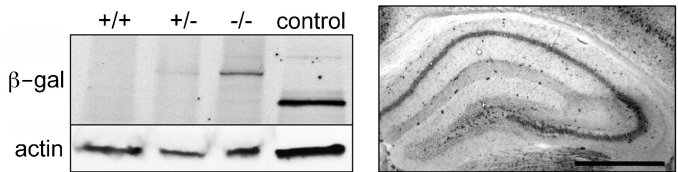

$\mathbf{L}$

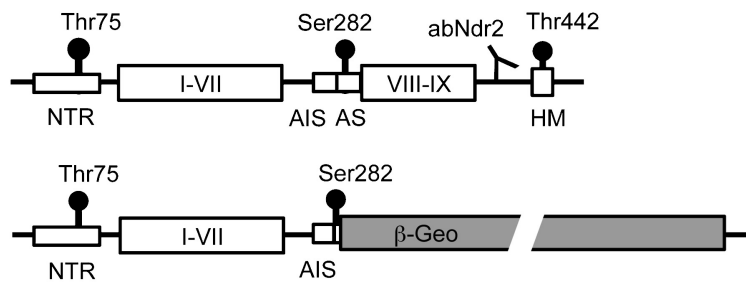

Figure 7. Ndr2 deficiency in hippocampal neurons leads to a reduced surface expression of activated $\beta 1$-integrin. Map2 and activated $\beta 1$-integrin were immune labeled in wild-type $(\boldsymbol{A}, \boldsymbol{B})$ and $\mathrm{Ndr} 2^{-I-}(\boldsymbol{C}, \boldsymbol{D})$ hippocampal neurons at DIV 3. Scale bars, $100 \mu \mathrm{m}$. $\boldsymbol{E}$, The number of dendrites was not significantly affected by Ndr2 deficiency, but tend to be reduced. $\boldsymbol{F}$, Ndr2 knock-down impairs integrin activation in dendrites, as indicated by lower level of $9 \mathrm{EG}$ labeled $\beta 1$-integrin. $n=19-22, N=3,{ }^{* * *} p<0.001$. G, Ndr2 gene ablation was achieved with a gene trap insertion of vector pGTOlxf between exons 9 and 10 of the Ndr2 gene (KOMP). Almost the entire cassette (bp 212- 8379), including a slice acceptor (SA), full $\beta$-galactosidase ( $\beta$-geo) coding sequence, and polyadenylation site, has been inserted. Arrows indicate the location of primers ge ${ }^{\mathrm{f} / \mathrm{r}}$ for confirmation of the ES cells, seqf ${ }^{/ \mathrm{r}}$ for sequencing of critical sites, and wt/ko ${ }^{\mathrm{f}}$, wt ${ }^{\mathrm{r}}$, ko ${ }^{\mathrm{r}}$ for genotyping. $\boldsymbol{H}$, Multiplex PCR detects specific signals for homozygous and heterozygous mutant mice, with the ko allele at 638 bp and the wt allele at 1098 bp fragment size. $I$, Western blot analysis with our c-terminal binding antibody for Ndr2 (abNdr2) confirms the loss of full-length Ndr2 protein from the hippocampus of Ndr2 ${ }^{-1-}$ mice and a reduced expression in Ndr2 ${ }^{ \pm}$mice. Beta-actin is used as a loading control. $\boldsymbol{J}, \mathrm{Ndr}_{1-282}:: \beta$-geo fusion protein was detected in $\mathrm{Ndr2}{ }^{-/-}$and $\mathrm{Ndr} 2^{+}$mice with a $33 \mathrm{kDa}$ molecular weight increase to $\beta$-galactosidase alone (control). $\boldsymbol{K}$, Staining of tissue sections with X-Gal substrate detects prominent expression of the inserted cassette in the hippocampus, particularly in area CA3, reflecting the high expression levels of Ndr2 mRNA in this region (Stork et al., 2004). Scale bar, $1 \mathrm{~mm}$. L, Scheme of $\mathrm{Ndr}_{1-282}:$ : $\beta$-geo fusion protein indicating the lack of most parts of the activating sequence, the kinase subdomains VIII-XII including the substrate recognition site, the c-terminal hydrophobic motif of the Ndr2 gene, as well as the Ndr2 antibody (abNdr2)-binding site (Stegert et al., 2004).

\section{Ndr2 modulates integrin trafficking}

The phosphorylation of $\beta 1$-integrin at $\mathrm{Thr}^{788 / 789}$ has been shown to protect it from lysosomal degradation and to enhance its cell surface expression (Böttcher et al., 2012). We, therefore, next investigated in HEK-293T cells whether Ndr2 may alter $\beta 1$ integrin endo- or exocytosis. Through FACS analysis with an antibody that detects the extracellular domain of native $\beta 1$ integrin we found that overexpression of the constitutively active LAT-Ndr2 enhances the exocytosis of $\beta 1$-integrins, whereas Ndr2 shRNA-mediated knock-down suppresses their recycling to the plasma membrane. In contrast, neither of these manipulations affected the endocytosis rate or total expression levels of $\beta 1$-integrin (Fig. 5).

\section{Ndr2 localizes at integrin-recycling endosomes}

Next, we examined whether Ndr2 may be associated with integrin-containing recycling vesicles in primary neurons. Indeed, we observed a colocalization of endogenous and transfected Ndr2 with various markers of the endosomal pathway, including EEA1 (data not shown), Rab5 (Fig. 6A-H), and Rab11 (Fig. 6I-P), as well as $\beta 1$-integrin in dendrites and somata of hippocampal neurons. Western blot analysis of isolated subcellular fractions from neural differentiated PC12 cells confirmed the expression of endogenous Ndr2 in early and recycling endosome containing fractions, again using Rab5 and Rab11 as markers (Fig. 6Q).

\section{Reduced $\beta 1$-integrin activation in outgrowing dendrites of} Ndr2-deficient neurons

Primary hippocampal neurons from $\mathrm{Ndr} 2^{-1-}$ mice (see Successful gene targeting in $\mathrm{Ndr} 2^{-/-}$mice, below) were used to determine whether Ndr2 deficiency also alters the amount of activated $\beta 1$-integrin on the surface of outgrowing dendrites. Using an antibody that detects $\beta 1$-integrins in their active conformation, we indeed found decrease in dendritic $\beta 1$-integrin labeling on DIV 3 hippocampal neurons derived from $\mathrm{Ndr} 2^{-1-}$ mice $(p<$ 0.001 , Student's $t$ test; Fig. $7 A-F)$.

Successful gene targeting in $\mathrm{Ndr} 2^{-/-}$mice

Ndr2-null mutant mice were generated by an insertion of a functional gene-trap cassette covering bp 212-8379 of vector pGT0lxF, including the splice acceptor site, full $\beta$-galactosidase- 
neomycin-phosphotransferase II ( $\beta$-geo) coding sequence, and polyadenylation site as confirmed with serial PCR and sequence analyses (see Fig. 7G, Table 1 for primers and their locations). The precise location in intron 9 was determined in the same manner: sequencing of a $638 \mathrm{bp}$ fragment generated with common forward primer wt/ko (position bp 596-615 of intron 9) and reverse primer ko (position bp 451-431 of the gene trap vector) unambiguously showed that the gene trap vector integrated at position bp 995 of intron 9 of the mouse Ndr2 gene (Fig. 7G).

Homozygous mutants were viable and $\mathrm{Ndr2}{ }^{ \pm} \times \mathrm{Ndr}^{ \pm}{ }^{ \pm}$breeding produced offspring with genotype distributions at Mendelian frequency. Western analysis confirmed the complete loss of full-length $\mathrm{Ndr} 2$ from the null mutant hippocampus (Fig. 7I). The gene trap insertion resulted in the generation of an $\mathrm{Ndr}_{1-282}: \because \beta$-geo fusion protein (Fig. $7 L$ ) with a predicted molecular weight of $140 \mathrm{kDa}$, deleting most of the activating sequence and kinase subdomains VIII-XII, including the substrate recognition site and the c-terminal hydrophobic motif of the Ndr2 gene (Stegert et al., 2004). Western analysis confirmed the expected $33 \mathrm{kDa}$ molecular weight increase of the $\mathrm{Ndr} 2_{1-282}: \%$-geo fusion protein in $\mathrm{Ndr} 2{ }^{ \pm}$and $\mathrm{Ndr} 2^{-I-}$ mice compared with $\beta$-geo (Fig. $7 J$ ). A complete loss of the $54 \mathrm{kDa}$ band in $\mathrm{Ndr} 2^{-1-}$ mice and a reduced signal in $\mathrm{Ndr} 2^{ \pm}$mice were found with an Ndr2-specific antibody (Stork et al., 2004) targeting the c-terminal region of the kinase.

\section{Ndr2-null mutant mice display premature branching phenotype}

To investigate the role of Ndr2 on neuronal differentiation in the hippocampus in vivo, we applied histological analysis of brain sections of Ndr2-null mice. An overall view of Nissl-stained tissue revealed (Fig. $8 A, B$ ) no overt alteration in hippocampal structure and lamination. However, an analysis of dendritic arborization with the Golgi impregnation method (Fig. 8C,D) showed a distinct morphological change of CA3 pyramidal neurons: whereas no significant differences in the basal dendrite branching was observed in the mature hippocampus of adult $\mathrm{Ndr2} 2^{-1-}$ mice (repeated-measures ANOVA with the betweensubject factor gene and the within-subject factor distance: $F_{(1,30)}$ $=0.065, p=0.301$ ), the apical dendritic tree was found to be altered in its complexity compared with wild-type littermates (Fig. $8 E$ ). In the proximal part, apical dendrites of $\mathrm{Ndr} 2^{-1-}$ mice (Fig. $8 E, J$ ) branch earlier and show an increased complexity (repeated-measures ANOVA: $F_{(1,25)}=5.295, p=$ 0.03 ), whereas a more distal part of the dendritic tree (Fig. $8 E, K)$ shows less branching $\left(F_{(1,25)}=5.389, p=0.029\right)$. This
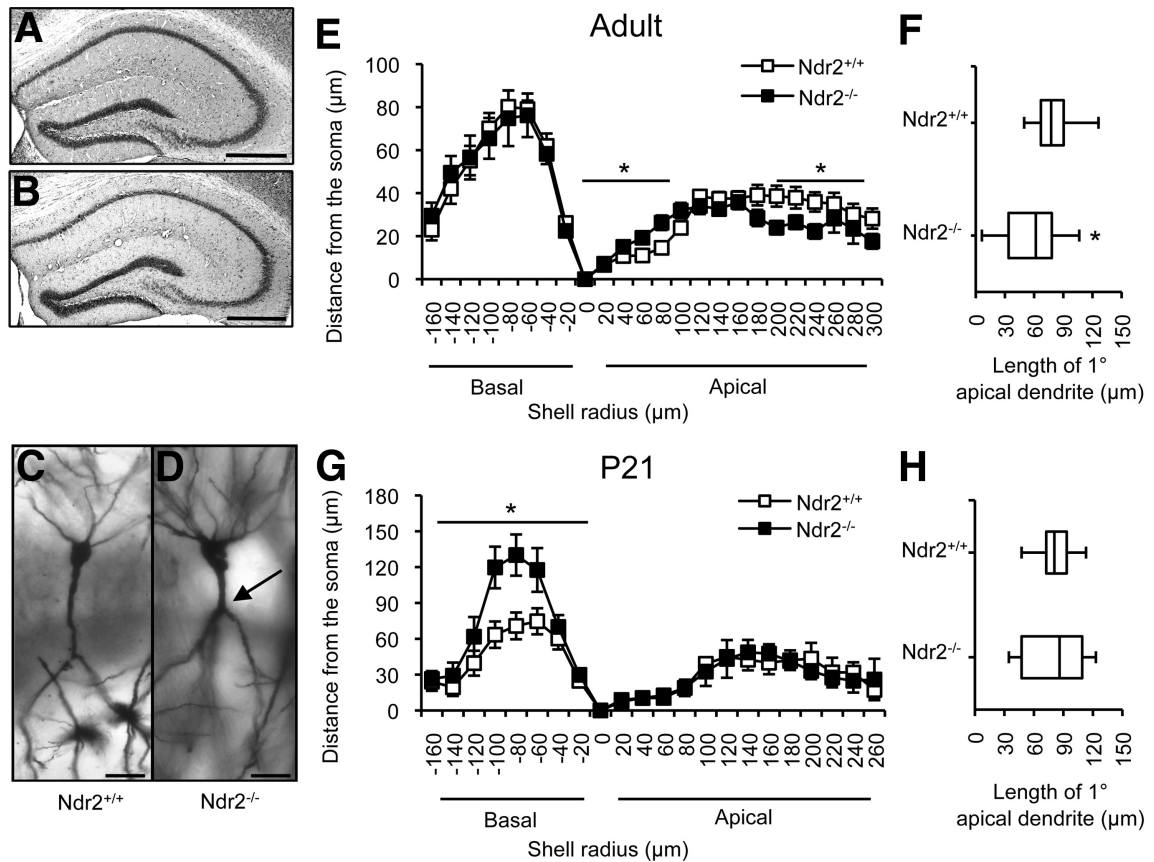

$\mathrm{H}$
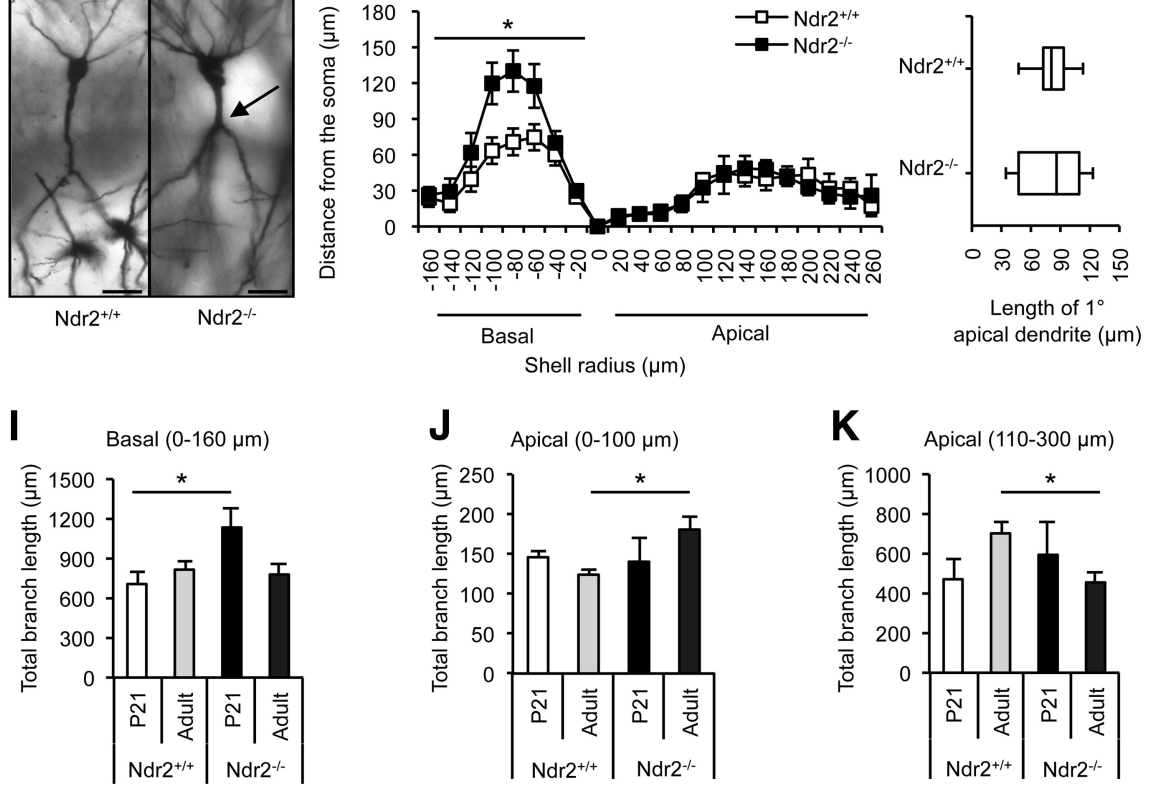

Figure 8. Adult $\mathrm{Ndr} 2^{-1-}$ mice show premature dendritic branching. Morphology of CA3 pyramidal cells was investigated in Golgi-stained tissue of $\mathrm{Ndr} 2^{-1-}$ mice and their wild-type littermates. $\boldsymbol{A}, \boldsymbol{B}$, No major change in hippocampus structure and lamination is observed in Ndr2-deficient mice (A) compared with their wild-type littermates $(\boldsymbol{B})$. Scale bar, $500 \mu \mathrm{m}$. C, D, However, Golgi staining of control animals $(\boldsymbol{C})$ and $\mathrm{Ndr}^{-1-}$ mice $(\boldsymbol{D})$ demonstrates a shortening in the initial segment and a premature branching (arrow) in hippocampal CA3 pyramidal neurons lacking the expression of full-length Ndr2. $\boldsymbol{E}$, Sholl analysis of traced CA3 pyramidal neurons reveals that proximal apical dendrites in adult $\mathrm{Ndr}^{-1-}$ mice ( $n=14$ cells each, $N=4-5$ mice per group) branch earlier and thus have more dendritic branches. Due to this early branching, there is a shift in the length of more distal

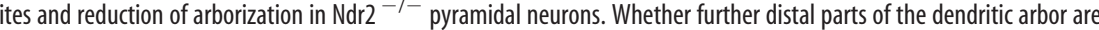
equally affected (Warren et al., 2012) remains to be determined. There is no difference in the basal dendrite complexity. $\boldsymbol{F}$, The length of the initial segment of CA3 pyramidal neurons is shorter in the $\mathrm{Ndr} 2^{-1-}$ mice compared with their wild-type littermates no difference in the apical dendrite complexity but does show overbranching in basal dendrites in the Ndr2 ${ }^{-1-}$ mice $(n=7-8$ cells each, $N=4-7$ mice per group). $\boldsymbol{H}$, At P21, the length of the primary segment of apical dendrites does not differ between $\mathrm{Ndr2}{ }^{+/+}$and Ndr2 ${ }^{-I-}$ mice ( $n=12-18$ cells each, $N=5-6$ mice per group). $I$, Mean total dendrite length of basal dendrites shows difference at P21 as the length of dendrites is increased in $\mathrm{Ndr} 2^{-/-}$mice. $\boldsymbol{J}, \boldsymbol{K}$, Mean total length of the proximal apical dendrites is increased in adult $\mathrm{Ndr} 2^{-/-}$mice $(\boldsymbol{J})$ and in more distal parts of apical dendrites $(\boldsymbol{K})$ there is a reduction compared with their wild-type littermates. Scale bars, $11 \mu \mathrm{m}$. Data are presented as mean \pm SEM. ${ }^{*} p<0.05$.

shift of arborization toward the soma is associated with a significant shortening in the length of the initial apical dendritic segment of adult $\mathrm{Ndr} 2^{-1-}$ mice (Fig. $8 F$ ) compared with wild types (Mann-Whitney $U$ test: $U=172.5, p<0.05$ ). In young, Ndr2-deficient mice (P21), no reduction is evident in the length of the initial segment (Fig. $8 H$, Mann-Whitney $U$ test: $\mathrm{U}=104, p>0.05)$ or in the complexity of the proximal (repeated-measures ANOVA: $\left.F_{(1,13)}=0.269, p=0.768\right)$ and more distal (repeated-measures ANOVA: $F_{(1,13)}=0.106, p=$ $0.9)$ part of their apical dendrites, respectively (Fig. $8 G, J, K$ ). However, an increased branching of basal dendrites is evident 

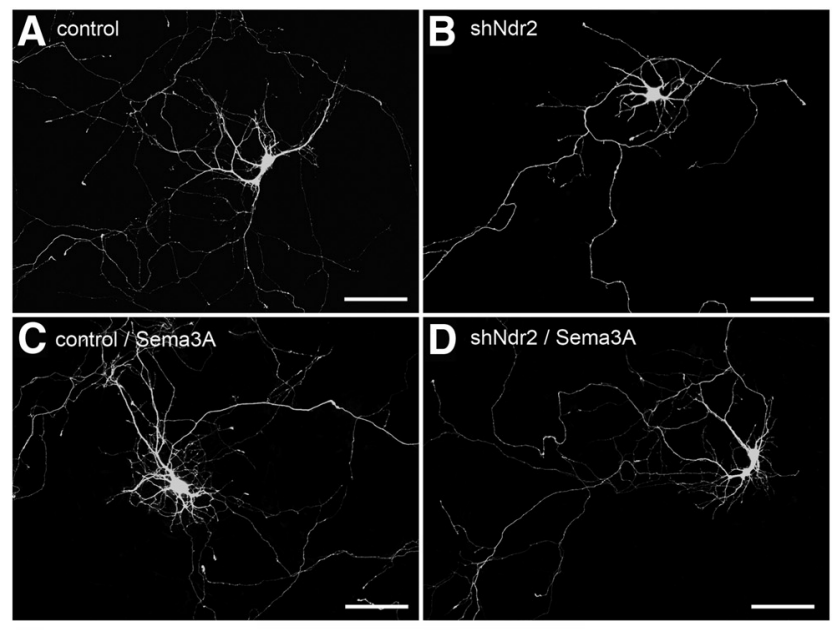

$\mathbf{E}$
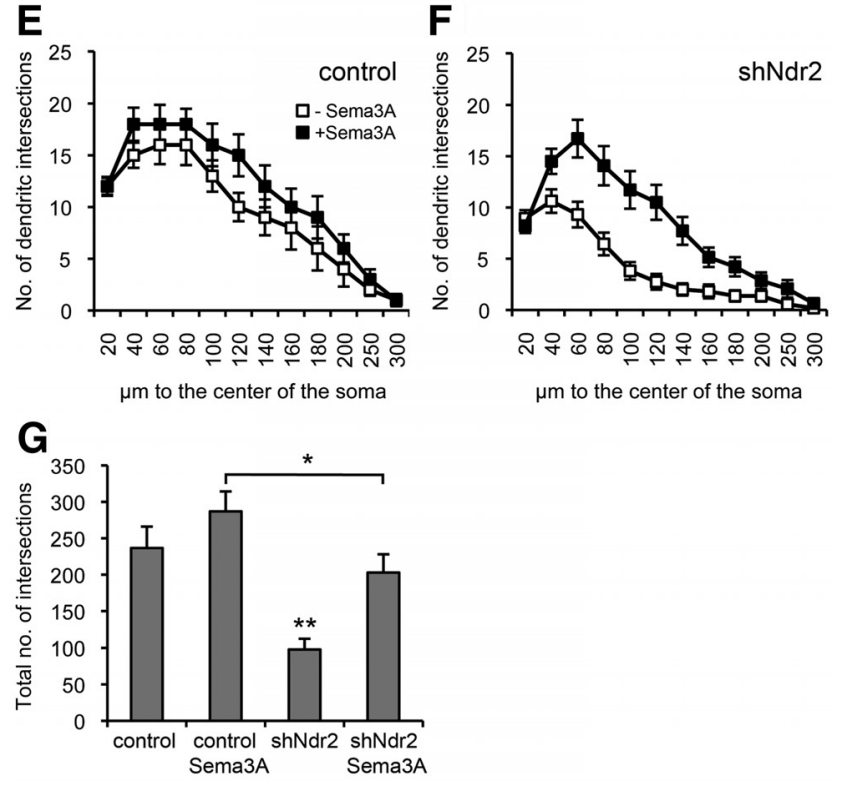

Figure 9. Sema3A partially recovers dendritic growth after Ndr2 knock-down. $\boldsymbol{A}, \boldsymbol{B}, \mathrm{Ndr2}$ knock-down-induced reduction of dendritic growth is evident in the absence of Sema3A treatment. C, D, Dendritic growth is stimulated in both controls and in shNdr2-treated neurons by Sema3A. However, a reduced level of differentiation is still evident in shNdr2 cells compared with the Sema3A-treated controls. $\boldsymbol{E}, \boldsymbol{F}$, Comparison of the number of dendritic intersections with the Sholl analysis confirms that application of Sema3A partially rescues dendritic growth in Ndr2 knock-down neurons ( $n=20$ cells each, $N=3$ ). $\mathbf{G}$, The total number of dendritic intersections is increased in shNdr2 cells, but does not reach levels of Sema3A-stimulated growth in control cells. Data are presented as mean \pm SEM. ${ }^{*} p<0.05,{ }^{* *} p<0.01$ compared with untreated controls (Fischer's PLSD).

in $\mathrm{Ndr} 2^{-1-}$ mice on P21 $\left(F_{(1,13)}=6.328, p=0.026\right)$ that cannot be observed in the adult knock-out mouse (Fig. $8 G, I$ ).

\section{Ndr2-dependent dendritic growth is responsive to Semaphorin $3 \mathrm{~A}$}

Semaphorin 3A (Sema3A) has been shown to stimulate dendritic growth in primary hippocampal neurons in a $\beta 1$-integrindependent manner (Schlomann et al., 2009). We tested whether Sema3A can rescue the knock-down-induced growth deficit or if the Sema3A effects themselves are sensitive to the Ndr2 knockdown (Fig. 9). In fact, we observed a general stimulation of dendritic growth by Sema3A (repeated-measures ANOVA: $F_{(1,28)}=$ $14.196, p=0.01$ ) and recovery of Ndr2 knock-down induced dendritic growth deficits indicating compensation through the
Sema3A stimulation (Fig. 9A-F). However, Sema3A induced dendrite growth in shNdr2-transfected neurons only to nonstimulated control levels (Fig. 9G). Ndr2 knock-down cells failed to reach the level of dendritic growth seen in control shRNAtransfected cells with Sema3A treatment (Fishers PLSD, $p=$ 0.016; Fig. 9), suggesting a contribution of Ndr2 to Sema3A growth signaling.

\section{Discussion}

Ndr kinases are targets of the Hippo signaling pathway and control centrosome duplication and alignment, cell-cycle exit, apoptosis, and cell polarity (Hergovich et al., 2006; Emoto, 2011). The mammalian Ndr kinases Lats1/2 and their invertebrate homologs have been implicated in the proliferation and differentiation of neural progenitors (Cao et al., 2008; Fernandez et al., 2009). Ndr1/2 and their homologs, in contrast, appear to be more relevant for neurite development (Emoto, 2011; Ultanir et al., 2012).

Here, we report the selective expression of $\mathrm{Ndr} 2$, but not $\mathrm{Ndr} 1$, in the developing mouse hippocampus and frontal cortex and its importance as a stimulator of $\beta 1$-integrin-dependent dendritic growth in mouse hippocampal neurons. This is in contrast to the rat hippocampus, in which both $\mathrm{Ndr} 1$ and Ndr2 kinase are expressed and Ndrl acts as a negative regulator of dendritic branching (Ultanir et al., 2012). However, rat Ndr1 function appears to be differentially regulated along the dendritic tree, because constitutively active Ndr1 also enhances distal dendritic branching. In the same study, Ndr2 was found to compensate for the loss of $\mathrm{Ndr1}$, but only a trend toward reduced dendrite branching was observed upon single Ndr2 knock-down.

In our experiments with primary mouse neurons, the effect of $\mathrm{Ndr} 2$ on neurite growth was more clearly evident, because its knock-down significantly reduced and its overexpression profoundly increased dendritic growth. Consistent with findings in C. elegans, we further observed that Ndr kinase function is not confined to dendritic, but is also involved in the control of axonal, growth (Zallen et al., 2000).

Considering the generally larger dendritic arborization in our cultures than those reported by Ultanir et al. (2012), we hypothesized that experimental conditions may account for the observed differences between studies. For example, in primary cell culture, astrocytic deposition of extracellular matrix components powerfully activates integrin-dependent neuronal growth (Nishio et al., 2003) and the Hippo kinase Mstl activates integrins in hematopoietic cells (Kliche et al., 2012). In fact, in our hippocampal cultures, growth deficits were also evident in shNdr2-treated cells plated on fibronectin instead of a gliaderived matrix and the overgrowth of dendrites and axons in $\mathrm{Ndr2}$-overexpressing cells was abolished through the application of the $\beta 1-/ \beta 3$-disintegrin echistatin. We found that $\beta 1$-integrin is the predominant of these two integrin isoforms in our neuronal cultures and that knock-down of $\beta 1$-integrin interferes with dendritic and axonal growth similar to Ndr2 knock-down. Such involvement of integrins in dendritic differentiation has been reported previously: the integrin ligand laminin-1 was found to enhance branching of dendrites and axons in mouse cortical primary neurons in an echistatin-sensitive manner (Moresco et al., 2005 ) and inactivation of $\beta 1$-integrins induced rapid retraction of dendrites in retinal ganglion cells (Marrs et al., 2006). More recently, $\beta 1$-integrins have been shown to facilitate both dendritic and axonal growth in hippocampal primary neurons (Schlomann et al., 2009; Tan et al., 2012). 
It is firmly established that, during endosomal trafficking and activation, $\beta 1$-integrin becomes phosphorylated at the cytoplasmic residues $\mathrm{Thr}^{788 / 789}$ (Nilsson et al., 2006). This phosphorylation site is involved in the binding of sorting nexin 17 and the protection of $\beta 1$-integrin from degradation; its inactivation through mutagenesis disturbs recycling to the cell surface without an alteration of internalization rates (Böttcher et al., 2012). Indeed, we observed that $\mathrm{Ndr} 2$ is able to stimulate both the phosphorylation of $\mathrm{Thr}^{788 / 789}$ and the exocytosis rate of $\beta 1$-integrin in HEK-293T cells. However, increased $\mathrm{Thr}^{788 / 789}$ phosphorylation upon Ndr2 activation apparently was not direct, but instead was dependent on PKC and CaMKII, which have also been reported to phosphorylate this site in other cellular systems (Suzuki and Takahashi, 2003; Stawowy et al., 2005). It is unlikely that these kinases act upstream of Ndr2, because $\mathrm{Thr}^{788 / 789}$ phosphorylation was stimulated by constitutively active Ndr2, but not by a constitutively active form of its upstream activator Mst1; rather, they appear to act as intermediate kinases and synergistically with $\mathrm{Ndr} 2$ in the activation of $\beta 1$-integrin. PKC $\varepsilon$, through phosphorylation of vimentin, is able to control the surface expression of $\beta 1$-integrin (Ivaska et al., 2005; Kim et al., 2010). CaMKIImediated $\mathrm{Ca}^{2+}$ signaling is known as critical regulator of dendritic differentiation (Fink et al., 2003; Konur and Ghosh, 2005) and $\mathrm{Ca}^{2+}$-dependent $\beta 1$-integrin recycling has been reported during axonal growth cone repulsion (Hines et al., 2010).

We further found that Ndr2 is associated with $\beta 1$-integrinpositive early and recycling endosomes in neuronal cells. Dynamin-dependent endocytosis, endosomal trafficking, and exocytosis are important steps in the control of integrinmediated growth. For example, integrins are internalized at the rear end of migrating cells and form new sites of adhesion at their leading edge (Ng et al., 1999; Zerial and McBride, 2001; Pellinen and Ivaska, 2006; Caswell et al., 2009). It is conceivable that Ndr2 may be recruited to integrin-containing endosomes to support the phosphorylation of $\beta 1$-integrins and their recycling. Achieving high-affinity conformation, however, further requires the assembly of intracellular binding partners such as talin and kindlin. Interestingly, the conserved TT (i.e., $\mathrm{Thr}^{788 / 789}$ of $\beta 1$-integrin) phosphorylation motif of $\beta$-integrins also plays a role in regulating the competitive association of these intracellular binding partners (Gahmberg et al., 2009).

Evidence suggests that recycling and activation of integrins at the plasma membrane are critically involved in neurite outgrowth: nerve growth factor induces accumulation of $\beta 1$ integrins in filopodial tips at axonal growth cones (Grabham and Goldberg, 1997) and stimulation of AMPA type glutamate receptors can lead to an increase of $\alpha 5$ - and $\beta 1$-integrins in the cell (Lin et al., 2005). $\alpha 5 \beta 1$-integrin relocalizes from somata to dendrites during dendrite formation and maturation in the course of the first two postnatal weeks in vivo (Bi et al., 2001) and $\beta 1$-integrin associates with integrin-linked kinase, which is required for the balance between axon and dendrite formation, at the dendritic tips of differentiating hippocampal neurons (Guo et al., 2007). Tan et al. (2012) have recently shown that kindlin-1 stimulates growth through associating with $\beta 1$-integrins in outgrowing axons. We found that the expression of activated $\beta 1$-integrin is reduced on dendrites of $\mathrm{Ndr} 2$ deficient primary neurons. Therefore, the ability of Ndr2 to control the phosphorylation of the cytoplasmic domain of $\beta 1$-integrin may well serve to regulate integrin activity during neural differentiation.

The relevance of these processes for hippocampal development is evident in $\mathrm{Ndr} 2^{-1-}$ mice. A gene trap insertion to intron 9 of the Ndr2 gene of these animals resulted in generation of a
$\mathrm{Ndr} 2_{1-282}:: \beta$-geo fusion protein with disrupted protein kinase domain. Because of the activity of the $\beta$-geo marker indicating pronounced expression in the hippocampal CA3 pyramidal cell layer of $\mathrm{Ndr} 2^{-I-}$ mice, we analyzed the dendritic structure of these neurons in mutant and wild types using the Golgi impregnation method. Our data indicate arbor- and layer-specific alterations of dendritic complexity in these cells during postnatal development and maturation. These observations are in agreement with a previous report on the role of $\beta 1$-integrin in the maturation and stabilization of hippocampal dendrites (Warren et al., 2012), although further work will be required to examine potential Ndr2 effects on distal parts of the apical dendrite. Ndr2mediated $\beta 1$-integrin activation may be used by locally acting growth signals for the fine regulation of dendritic structure. For example, CA3 hippocampal neurons express neuropilins and plexin-A1, plexin-A2, and plexin-A3, which can act as receptors for Sema 3A and Sema 3F (Chédotal et al., 1998; Murakami et al., 2001; Pozas et al., 2001). Sema3A has been shown to stimulate dendritic growth in hippocampal primary neurons by activating $\beta 1$-integrins (Schlomann et al., 2009). Strikingly, the phenotype of $\mathrm{Ndr} 2^{-1-}$ mice resembles that of Sema3 $\mathrm{A}^{-1-}$ mice in that $\sim 1 / 3$ of adult pyramidal cells showed a premature branching (Nakamura et al., 2009).

We therefore finally tested the effect of Sema3A on hippocampal primary neurons and found that it recovers dendritic growth in neurons with $\mathrm{Ndr} 2$ knock-down to levels that are comparable to those of untreated control cells. However, shNdr2-treated cells did not reach the level of dendritic growth of control neurons under Sema3A stimulation. Therefore, Sema3Ainduced, integrin-dependent dendritic growth appears to interact with the expression of Ndr2. Semaphorins are known to control neuronal differentiation through various signaling pathways (Pasterkamp, 2012) and, intriguingly, both Ndr1 and Ndr2 have been shown to interact with MICAL-1 (molecule interacting with CasL-1), an enzyme that links semaphorins to F-actin rearrangement during axonal and dendritic growth. MICAL-1 inhibits $\mathrm{Ndr} 1 / 2$ by competing with Mst kinases for binding at the hydrophobic motif and it has been suggested that semaphorins may disinhibit the kinase by sequestering MICAL (Hung et al., 2010; Zhou et al., 2011). Ndr kinases and semaphorins thus seem to interact in the intracellular signaling pathways that lead to $\beta 1$-integrin activation in differentiating neuronal cells.

\section{Conclusions}

The control of neurite formation and branching is fundamental to the development of neuronal circuits. $\mathrm{Ndr}$ family kinases play multiple roles in these processes and do so, at least in part, by regulating the intracellular trafficking and the activation of $\beta$-integrins. The activation of integrins appears to be an important general function of the Hippo signaling pathway, which has been described previously for T cells (Katagiri et al., 2009; Ueda et al., 2012).

\section{References}

Abram CL, Lowell CA (2009) The ins and outs of leukocyte integrin signaling. Annu Rev Immunol 27:339-362. CrossRef Medline

Banker G, Goslin K (1988) Developments in neuronal cell culture. Nature 336:185-186. CrossRef Medline

Bernard-Trifilo JA, Kramár EA, Torp R, Lin CY, Pineda EA, Lynch G, Gall CM (2005) Integrin signaling cascades are operational in adult hippocampal synapses and modulate NMDA receptor physiology. J Neurochem 93:834-849. CrossRef Medline

Bi X, Lynch G, Zhou J, Gall CM (2001) Polarized distribution of alpha5 integrin in dendrites of hippocampal and cortical neurons. J Comp Neurol 435:184-193. CrossRef Medline 
Boerth NJ, Sadler JJ, Bauer DE, Clements JL, Gheith SM, Koretzky GA (2000) Recruitment of SLP-76 to the membrane and glycolipid-enriched membrane microdomains replaces the requirement for linker for activation of $\mathrm{T}$ cells in T cell receptor signaling. J Exp Med 192:1047-1058. CrossRef Medline

Böttcher RT, Stremmel C, Meves A, Meyer H, Widmaier M, Tseng HY, Fässler R (2012) Sorting nexin 17 prevents lysosomal degradation of betal integrins by binding to the betal-integrin tail. Nat Cell Biol 14:584592. CrossRef Medline

Cao X, Pfaff SL, Gage FH (2008) YAP regulates neural progenitor cell number via the TEA domain transcription factor. Genes Dev 22:3320-3334. CrossRef Medline

Caswell PT, Vadrevu S, Norman JC (2009) Integrins: masters and slaves of endocytic transport. Nat Rev Mol Cell Biol 10:843-853. CrossRef Medline

Chédotal A, Del Rio JA, Ruiz M, He Z, Borrell V, de Castro F, Ezan F, Goodman CS, Tessier-Lavigne M, Sotelo C, Soriano E (1998) Semaphorins III and IV repel hippocampal axons via two distinct receptors. Development 125:4313-4323. Medline

Clegg DO, Wingerd KL, Hikita ST, Tolhurst EC (2003) Integrins in the development, function and dysfunction of the nervous system. Front Biosci 8:d723-750. CrossRef Medline

Emoto K (2011) The growing role of the Hippo-NDR kinase signalling in neuronal development and disease. J Biochem 150:133-141. CrossRef Medline

Emoto K, He Y, Ye B, Grueber WB, Adler PN, Jan LY, Jan YN (2004) Control of dendritic branching and tiling by the Tricornered-kinase/Furry signaling pathway in Drosophila sensory neurons. Cell 119:245-256. CrossRef Medline

Emoto K, Parrish JZ, Jan LY, Jan YN (2006) The tumour suppressor Hippo acts with the NDR kinases in dendritic tiling and maintenance. Nature 443:210-213. CrossRef Medline

Eppig JT, Blake JA, Bult CJ, Kadin JA, Richardson JE; Mouse Genome Database Group (2012) The Mouse Genome Database (MGD): comprehensive resource for genetics and genomics of the laboratory mouse. Nucleic Acids Res 40:D881-D886. CrossRef Medline

Fang X, Adler PN (2010) Regulation of cell shape, wing hair initiation and the actin cytoskeleton by Trc/Fry and Wts/Mats complexes. Dev Biol 341:360-374. CrossRef Medline

Fernandez-L A, Northcott PA, Dalton J, Fraga C, Ellison D, Angers S, Taylor MD, Kenney AM (2009) YAP1 is amplified and up-regulated in hedgehog-associated medulloblastomas and mediates Sonic hedgehogdriven neural precursor proliferation. Genes Dev 23:2729-2741. CrossRef Medline

Fink CC, Bayer KU, Myers JW, Ferrell JE Jr, Schulman H, Meyer T (2003) Selective regulation of neurite extension and synapse formation by the beta but not the alpha isoform of CaMKII. Neuron 39:283-297. CrossRef Medline

Gahmberg CG, Fagerholm SC, Nurmi SM, Chavakis T, Marchesan S, Gronholm M (2009) Regulation of integrin activity and signalling. Biochim Biophys Acta 1790:431-444. CrossRef Medline

Gallegos ME, Bargmann CI (2004) Mechanosensory neurite termination and tiling depend on SAX-2 and the SAX-1 kinase. Neuron 44:239-249. CrossRef Medline

Glaser EM, Van der Loos H (1981) Analysis of thick brain sections by obverse-reverse computer microscopy: application of a new, high clarity Golgi-Nissl stain. J Neurosci Methods 4:117-125. CrossRef Medline

Goslin K, Banker G (1990) Rapid changes in the distribution of GAP-43 correlate with the expression of neuronal polarity during normal development and under experimental conditions. J Cell Biol 110:1319-1331. CrossRef Medline

Grabham PW, Goldberg DJ (1997) Nerve growth factor stimulates the accumulation of betal integrin at the tips of filopodia in the growth cones of sympathetic neurons. J Neurosci 17:5455-5465. Medline

Guo W, Jiang H, Gray V, Dedhar S, Rao Y (2007) Role of the integrin-linked kinase (ILK) in determining neuronal polarity. Dev Biol 306:457-468. CrossRef Medline

Gupton SL, Gertler FB (2010) Integrin signaling switches the cytoskeletal and exocytic machinery that drives neuritogenesis. Dev Cell 18:725-736. CrossRef Medline

Harburger DS, Calderwood DA (2009) Integrin signalling at a glance. J Cell Sci 122:159-163. CrossRef Medline
Hayakawa A, Hayes SJ, Lawe DC, Sudharshan E, Tuft R, Fogarty K, Lambright D, Corvera S (2004) Structural basis for endosomal targeting by FYVE domains. J Biol Chem 279:5958-5966. CrossRef Medline

Hergovich A, Stegert MR, Schmitz D, Hemmings BA (2006) NDR kinases regulate essential cell processes from yeast to humans. Nat Rev Mol Cell Biol 7:253-264. CrossRef Medline

Hines JH, Abu-Rub M, Henley JR (2010) Asymmetric endocytosis and remodeling of betal-integrin adhesions during growth cone chemorepulsion by MAG. Nat Neurosci 13:829-837. CrossRef Medline

Hung RJ, Yazdani U, Yoon J, Wu H, Yang T, Gupta N, Huang Z, van Berkel WJ, Terman JR (2010) Mical links semaphorins to F-actin disassembly. Nature 463:823-827. CrossRef Medline

Huveneers S, Danen EH (2009) Adhesion signaling- crosstalk between integrins, Src and Rho. J Cell Sci 122:1059-1069. CrossRef Medline

Ishida A, Kameshita I, Okuno S, Kitani T, Fujisawa H (1995) A novel highly specific and potent inhibitor of calmodulin-dependent protein kinase II. Biochem Biophys Res Comm 212:806-812. CrossRef Medline

Ivaska J, Vuoriluoto K, Huovinen T, Izawa I, Inagaki M, Parker PJ (2005) PKCepsilon-mediated phosphorylation of vimentin controls integrin recycling and motility. EMBO J 24:3834-3845. CrossRef Medline

Kaech S, Banker G (2006) Culturing hippocampal neurons. Nat Protoc 1:2406-2415. CrossRef Medline

Katagiri K, Katakai T, Ebisuno Y, Ueda Y, Okada T, Kinashi T (2009) Mst1 controls lymphocyte trafficking and interstitial motility within lymph nodes. EMBO J 28:1319-1331. CrossRef Medline

Kim H, Nakamura F, Lee W, Shifrin Y, Arora P, McCulloch CA (2010) Filamin $\mathrm{A}$ is required for vimentin-mediated cell adhesion and spreading. Am J Physiol Cell Physiol 298:C221-236. CrossRef Medline

Kliche S, Worbs T, Wang X, Degen J, Patzak I, Meineke B, Togni M, Moser M, Reinhold A, Kiefer F, Freund C, Förster R, Schraven B (2012) CCR7mediated LFA-1 functions in T cells are regulated by 2 independent ADAP/SKAP55 modules. Blood 119:777-785. CrossRef Medline

Köhrmann M, Haubensak W, Hemraj I, Kaether C, Lessmann VJ, Kiebler MA (1999) Fast, convenient, and effective method to transiently transfect primary hippocampal neurons. J Neurosci Res 58:831-835. CrossRef Medline

Konur S, Ghosh A (2005) Calcium signaling and the control of dendritic development. Neuron 46:401-405. CrossRef Medline

Larjava H, Plow EF, Wu C (2008) Kindlins: essential regulators of integrin signalling and cell-matrix adhesion. EMBO Rep 9:1203-1208. CrossRef Medline

Lei WL, Xing SG, Deng CY, Ju XC, Jiang XY, Luo ZG (2012) Laminin/beta1 integrin signal triggers axon formation by promoting microtubule assembly and stabilization. Cell Res 22:954-972. CrossRef Medline

Lin CY, Lynch G, Gall CM (2005) AMPA receptor stimulation increases alpha5beta1 integrin surface expression, adhesive function and signaling. J Neurochem 94:531-546. CrossRef Medline

Margadant C, Monsuur HN, Norman JC, Sonnenberg A (2011) Mechanisms of integrin activation and trafficking. Curr Opin Cell Biol 23:607614. CrossRef Medline

Marrs GS, Honda T, Fuller L, Thangavel R, Balsamo J, Lilien J, Dailey ME Arregui C (2006) Dendritic arbors of developing retinal ganglion cells are stabilized by beta 1-integrins. Mol Cell Neurosci 32:230-241. CrossRef Medline

McGeachie AB, Cingolani LA, Goda Y (2011) Stabilising influence: integrins in regulation of synaptic plasticity. Neurosci Res 70:24-29. CrossRef Medline

Moresco EM, Donaldson S, Williamson A, Koleske AJ (2005) Integrinmediated dendrite branch maintenance requires Abelson (Abl) family kinases. J Neurosci 25:6105-6118. CrossRef Medline

Moser M, Legate KR, Zent R, Fässler R (2009a) The tail of integrins, talin, and kindlins. Science 324:895-899. CrossRef Medline

Moser M, Bauer M, Schmid S, Ruppert R, Schmidt S, Sixt M, Wang HV, Sperandio M, Fässler R (2009b) Kindlin-3 is required for beta2 integrinmediated leukocyte adhesion to endothelial cells. Nat Med 15:300-305. CrossRef Medline

Murakami Y, Suto F, Shimizu M, Shinoda T, Kameyama T, Fujisawa H (2001) Differential expression of plexin-A subfamily members in the mouse nervous system. Dev Dyn 220:246-258. CrossRef Medline

Mylius J, Brosch M, Scheich H, Budinger E (2013) Subcortical auditory structures in the mongolian gerbil: I. Golgi architecture. J Comp Neurol 521:1289-1321. CrossRef Medline 
Nakamura F, Ugajin K, Yamashita N, Okada T, Uchida Y, Taniguchi M, Ohshima T, Goshima Y (2009) Increased proximal bifurcation of CA1 pyramidal apical dendrites in sema3A mutant mice. J Comp Neurol 516: 360-375. CrossRef Medline

Ng T, Shima D, Squire A, Bastiaens PI, Gschmeissner S, Humphries MJ, Parker PJ (1999) PKCalpha regulates betal integrin-dependent cell motility through association and control of integrin traffic. EMBO J 18: 3909-3923. CrossRef Medline

Nilsson S, Kaniowska D, Brakebusch C, Fässler R, Johansson S (2006) Threonine 788 in integrin subunit betal regulates integrin activation. Exp Cell Res 312:844-853. CrossRef Medline

Nishio T, Kawaguchi S, Iseda T, Kawasaki T, Hase T (2003) Secretion of tenascin-C by cultured astrocytes: regulation of cell proliferation and process elongation. Brain Res 990:129-140. CrossRef Medline

Pasterkamp RJ (2012) Getting neural circuits into shape with semaphorins. Nat Rev Neurosci 13:605-618. CrossRef Medline

Pellinen T, Ivaska J (2006) Integrin traffic. J Cell Sci 119:3723-3731. CrossRef Medline

Pozas E, Pascual M, Nguyen Ba-Charvet KT, Guijarro P, Sotelo C, Chédotal A, Del Río JA, Soriano E (2001) Age-dependent effects of secreted Semaphorins $3 \mathrm{~A}, 3 \mathrm{~F}$, and $3 \mathrm{E}$ on developing hippocampal axons: in vitro effects and phenotype of Semaphorin 3A (-/-) mice. Mol Cell Neurosci 18:2643. CrossRef Medline

Schlomann U, Schwamborn JC, Müller M, Fässler R, Püschel AW (2009) The stimulation of dendrite growth by Sema3A requires integrin engagement and focal adhesion kinase. J Cell Sci 122:2034-2042. CrossRef Medline

Sholl DA (1953) Dendritic organization in the neurons of the visual and motor cortices of the cat. J Anat 87:387-406. Medline

Stawowy P, Margeta C, Blaschke F, Lindschau C, Spencer-Hänsch C, Leitges M, Biagini G, Fleck E, Graf K (2005) Protein kinase C epsilon mediates angiotensin II-induced activation of betal-integrins in cardiac fibroblasts. Cardiovasc Res 67:50-59. CrossRef Medline

Stegert MR, Tamaskovic R, Bichsel SJ, Hergovich A, Hemmings BA (2004) Regulation of NDR2 protein kinase by multi-site phosphorylation and the S100B calcium-binding protein. J Biol Chem 279:23806-23812. CrossRef Medline

Stork O, Zhdanov A, Kudersky A, Yoshikawa T, Obata K, Pape HC (2004) Neuronal functions of the novel serine/threonine kinase Ndr2. J Biol Chem 279:45773-45781. CrossRef Medline

Stryke D, Kawamoto M, Huang CC, Johns SJ, King LA, Harper CA, Meng EC, Lee RE, Yee A, L'Italien L, Chuang PT, Young SG, Skarnes WC, Babbitt PC, Ferrin TE (2003) BayGenomics: a resource of insertional mutations in mouse embryonic stem cells. Nucleic Acids Res 31:278-281. CrossRef Medline

Suzuki K, Takahashi K (2003) Reduced cell adhesion during mitosis by threonine phosphorylation of betal integrin. J Cell Physiol 197:297-305. CrossRef Medline

Tan CL, Andrews MR, Kwok JC, Heintz TG, Gumy LF, Fässler R, Fawcett JW (2012) Kindlin-1 enhances axon growth on inhibitory chondroitin sulfate proteoglycans and promotes sensory axon regeneration. J Neurosci 32:7325-7335. CrossRef Medline

Turner NA, Rumsby MG, Walker JH, McMorris FA, Ball SG, Vaughan PF (1994) A role for protein kinase C subtypes alpha and epsilon in phorbolester-enhanced $\mathrm{K}(+)$ - and carbachol-evoked noradrenaline release from the human neuroblastoma SH-SY5Y. Biochem J 297:407-413. Medline

Ueda Y, Katagiri K, Tomiyama T, Yasuda K, Habiro K, Katakai T, Ikehara S, Matsumoto M, Kinashi T (2012) Mstl regulates integrin-dependent thymocyte trafficking and antigen recognition in the thymus. Nat Commun 3:1098. CrossRef Medline

Ultanir SK, Hertz NT, Li G, Ge WP, Burlingame AL, Pleasure SJ, Shokat KM, Jan LY, Jan YN (2012) Chemical genetic identification of NDR1/2 kinase substrates AAK1 and Rabin8 Uncovers their roles in dendrite arborization and spine development. Neuron 73:1127-1142. CrossRef Medline

Warren MS, Bradley WD, Gourley SL, Lin YC, Simpson MA, Reichardt LF, Greer CA, Taylor JR, Koleske AJ (2012) Integrin betal signals through Arg to regulate postnatal dendritic arborization, synapse density, and behavior. J Neurosci 32:2824-2834. CrossRef Medline

Waugh MG, Chu KM, Clayton EL, Minogue S, Hsuan JJ (2011) Detergentfree isolation and characterization of cholesterol-rich membrane domains from trans-Golgi network vesicles. J Lipid Res 52:582-589. CrossRef Medline

Zallen JA, Kirch SA, Bargmann CI (1999) Genes required for axon pathfinding and extension in the C. elegans nerve ring. Development 126:36793692. Medline

Zallen JA, Peckol EL, Tobin DM, Bargmann CI (2000) Neuronal cell shape and neurite initiation are regulated by the Ndr kinase SAX-1, a member of the Orb6/COT-1/warts serine/threonine kinase family. Mol Biol Cell 11: 3177-3190. CrossRef Medline

Zerial M, McBride H (2001) Rab proteins as membrane organizers. Nat Rev Mol Cell Biol 2:107-117. CrossRef Medline

Zhou Y, Gunput RA, Adolfs Y, Pasterkamp RJ (2011) MICALs in control of the cytoskeleton, exocytosis, and cell death. Cell Mol Life Sci 68:40334044. CrossRef Medline 